\title{
O CÓDIGO FLORESTAL DE 2012 SOB A ÓTICA DO SUPREMO TRIBUNAL FEDERAL: A CONSOLIDAÇÃO DO RETROCESSO SOCIOAMBIENTAL
}

\section{BRAZILIAN FOREST CODE OF 2012 ACCORDING TO THE SUPREME COURT: THE CONSOLIDATION OF SOCIAL AND ENVIRONMENTAL RETROGRESSION}

\author{
Danielle de Andrade Moreira ${ }^{1}$ \\ Daniela Marques de Carvalho de Oliveira² \\ Letícia Maria Rêgo Teixeira Lima ${ }^{3}$
}

\section{RESUMO}

Este artigo objetiva demonstrar que, além da dificuldade de implementação das normas ambientais já existentes, o Direito Ambiental enfrenta novo desafio: a edição de diplomas normativos tendentes a

\footnotetext{
${ }^{1}$ Doutora e Mestre em Direito pela Universidade do Estado do Rio de Janeiro (UERJ). Professora Adjunta da Pontifícia Universidade Católica do Rio de Janeiro, com atuação junto ao Programa de Pós-Graduação em Direito e ao Núcleo Interdisciplinar de Meio Ambiente (NIMA/PUC-Rio). Coordenadora do Grupo de Pesquisa Direito, Ambiente e Justiça no Antropoceno (JUMA) do NIMA/PUC-Rio. Membro do Conselho Consultivo do NIMA/PUC-Rio. Coordenadora Acadêmica do Curso de Pós-Graduação Lato Sensu (nível especialização) em Direito Ambiental da PUC-Rio. Sóciafundadora e coordenadora acadêmica da Associação dos Professores de Direito Ambiental do Brasil (APRODAB). VicePresidente da Região Sudeste do Instituto "O Direito por um Planeta Verde". Vice-Presidente do Conselho Deliberativo do Fundo Brasileiro para a Biodiversidade (FUNBIO). Ex-assessora jurídica do FUNBIO, da Fundação Estado de Engenharia do Meio Ambiente (FEEMA, atual INEA) e da Fundação Instituto Estadual de Florestas (IEF/RJ, atual INEA). Pontifícia Universidade Católica do Rio de Janeiro - PUC-Rio, Rio de Janeiro - Brasil. ORCID Id: https://orcid.org/0000-0001-8860-7963 Lattes: http://lattes.cnpq.br/5218215240161035 E-mail: daniamoreira@puc-rio.br

${ }^{2}$ Doutoranda e Mestre em Teoria do Estado e Direito Constitucional pela Pontifícia Universidade Católica do Rio de Janeiro (PUC-Rio). Pós-graduada (especialista) em Direito Ambiental Brasileiro pela PUC-Rio. Bacharel em Direito pela PUC-Rio. Pesquisadora do Grupo de Pesquisa Direito, Ambiente e Justiça no Antropoceno (JUMA) do Núcleo Interdisciplinar de Meio Ambiente da PUC-Rio (NIMA/PUC-Rio) e do Climate Policy Initiative (PCI/PUC-Rio). Pontifícia Universidade Católica do Rio de Janeiro - PUC-Rio, Rio de Janeiro - Brasil Lattes: http://lattes.cnpq.br/0313482079682232 E-mail: oliveiradaniela1985@gmail.com

${ }^{3}$ Mestre em Teoria do Estado e Direito Constitucional pela Pontifícia Universidade Católica do Rio de Janeiro (PUCRio), com bolsa de desempenho acadêmico (FAPERJ/Programa Bolsa Nota 10). Especialista em Direito Ambiental Brasileiro pela Pontifícia Universidade Católica do Rio de Janeiro (PUC-Rio). Bacharel em Direito pela Pontifícia Universidade Católica do Rio de Janeiro (PUC-Rio). Membro do Grupo de Pesquisa em Direito Ambiente e Justiça (JUMA) do Núcleo Interdisciplinar de Meio Ambiente (NIMA-Jur) da Pontifícia Universidade Católica do Rio de Janeiro PUC-Rio. Pontifícia Universidade Católica do Rio de Janeiro - PUC-Rio, Rio de Janeiro - Brasil. Lattes: http://lattes.cnpq.br/8687328818119325 E-mail: leticialima.ambiental@gmail.com
} 
reduzir direitos socioambientais já positivados. O Código Florestal de 2012 se insere neste contexto e é, até o momento, o principal exemplo concretizado de diminuição da proteção ao meio ambiente, em desrespeito ao princípio da vedação ao retrocesso socioambiental, cuja função é garantir que o nível de proteção alcançado pelos direitos socioambientais não seja reduzido, impedindo agressões ao núcleo essencial do direito fundamental ao meio ambiente ecologicamente equilibrado. Para o estudo dos retrocessos promovidos pela nova legislação florestal, foi realizado levantamento bibliográfico e documental, acompanhado de catalogação e análise crítica do material selecionado. A metodologia adotada incluiu levantamento, sistematização e análise qualitativa dos acórdãos do Supremo Tribunal Federal relativos às ações judiciais que questionavam a constitucionalidade de diversos dispositivos do novo Código Florestal. Ao declarar a constitucionalidade da grande maioria das alterações da Lei $12.651 / 2012$, o Supremo Tribunal Federal confirmou e consolidou um conjunto de retrocessos normativos em matéria de meio ambiente, esvaziando de modo substancial a orientação do princípio da vedação ao retrocesso socioambiental.

Palavras-chave: Código Florestal de 2012; Princípio da vedação ao retrocesso socioambiental; Área de Preservação Permanente; Reserva Legal; Área Rural Consolidada.

\section{ABSTRACT}

This article aims to demonstrate that, in addition to the difficulty of implementing existing environmental legislation, Environmental Law faces a new challenge: the issue of normative diplomas aimed at reducing social and environmental rights that are already in force. The 2012 Forest Code is part of this context and is, so far, the main example of a reduction in the protection of the environment, in violation of the principle of prohibition of social and environmental retrogression, which function is to ensure that the level of protection achieved by social and environmental rights is not reduced, preventing aggressions to the core of the fundamental right to an ecologically balanced environment. To study the retrogressions promoted by the new forest legislation, a bibliographic and documentary survey was carried out, along with cataloging and critical analysis of the selected material. The methodology adopted included a survey, systematization and qualitative analysis of the Federal Supreme Court decisions concerning lawsuits that questioned the constitutionality of various provisions of the new Forest Code. By declaring the constitutionality of the vast majority of amendments to Law $12,651 / 2012$, the Federal Supreme Court 
confirmed and consolidated a set of normative setbacks in environmental matters, substantially emptying the principle of prohibition of social and environmental retrogression.

Keywords: 2012 Forest Code; principle of prohibition of social and environmental retrogression; permanent preservation area; legal reserve; consolidated rural area.

\section{INTRODUÇÃO}

O presente ensaio parte da premissa de que o sistema jurídico-ambiental brasileiro é essencialmente preventivo, voltado para garantir a manutenção do equilíbrio socioambiental - ainda que mecanismos de reparação e de repressão também sejam necessários -, tendo em vista o respeito ao direito de todos ao meio ambiente ecologicamente equilibrado. Daí a importância da existência de normas capazes de garantir a manutenção e a proteção de florestas e demais formas de vegetação, como as que constam - ou deveriam constar - no Código Florestal.

O desafio da implementação do arcabouço normativo existente sempre foi reconhecido como fundamental para afastar o caráter "teatral" ${ }^{4}$ do Direito Ambiental brasileiro. Ocorre que, a este desafio soma-se outro, mais recente e ainda mais complexo: o ataque a direitos socioambientais consolidados. A onda de retrocessos e de ameaça de retrocessos que assola o Direito Ambiental brasileiro colocou em evidência o princípio da vedação ao retrocesso socioambiental, sua importância, orientação e alcance.

As tendências retrocessivas ganharam especial proporção a partir da edição do atual Código Florestal, instituído pela Lei 12.651/2012 (BRASIL, 2012a), em substituição ao Código de 1965 (Lei 4.771/1965). Trata-se do principal exemplo de retrocesso socioambiental já implementado no Brasil, cuja magnitude pode ser identificada a partir do histórico do tratamento normativo conferido às florestas no Brasil.

O retrocesso promovido pela Lei $12.651 / 2012$ foi, lamentavelmente, consolidado com o julgamento pelo Supremo Tribunal Federal (STF) das ações diretas de inconstitucionalidade que impugnavam vários dispositivos do novo Código Florestal, com base no argumento de violação do núcleo

\footnotetext{
${ }^{4}$ Expressão de Antônio Herman Benjamin (cf. BENJAMIN, 2010).
} 
essencial do direito fundamental ao meio ambiente ecologicamente equilibrado e do princípio da vedação ao retrocesso socioambiental. Pretende-se analisar neste texto as principais razões pelas quais se pode compreender que o STF, neste caso, desconsiderou - ou esvaziou de modo substancial - a orientação do princípio da vedação ao retrocesso socioambiental ao declarar constitucionais dispositivos legais que flexibilizaram ao ponto de enfraquecer significativamente as regras relativas à proteção florestal no Brasil.

Para tanto, o texto partirá da contextualização do princípio da vedação do retrocesso socioambiental no Direito Ambiental, considerando especialmente sua fundamentação, orientação, abrangência e importância, assim como alguns exemplos de sua aplicação pelo STF em outros casos, que não os relativos ao julgamento das ações constitucionais sobre o novo Código Florestal. Em seguida, serão apresentadas, em linhas gerais, as principais características do regime brasileiro de proteção das florestas desde o primeiro Código Florestal brasileiro (Decreto 23.793/1934), passando pelo Código Florestal de 1965 (Lei 4.771/1965), para que, então, seja possível identificar momentos do novo Código Florestal (Lei 12.651/2012) que concretizam retrocessos socioambientais. Esta análise será acompanhada por referências a posicionamentos - divergentes ou convergentes - dos ministros do STF com relação à (in)constitucionalidade dos vários trechos do novo Código Florestal impugnados, de modo que seja possível compreender os diferentes entendimentos e os fundamentos para a decisão final.

Assim, este artigo objetiva demonstrar que, além da dificuldade de implementação das normas ambientais já existentes, o Direito Ambiental enfrenta novo desafio: a edição de diplomas normativos tendentes a reduzir direitos socioambientais já positivados, tal como o Código Florestal de 2012, em franco desrespeito ao princípio da vedação ao retrocesso socioambiental, cuja função é garantir que o nível de proteção alcançado pelos direitos socioambientais não seja reduzido, impedindo agressões ao núcleo essencial do direito fundamental ao meio ambiente ecologicamente equilibrado. O estudo dos retrocessos promovidos pela nova legislação florestal, pauta-se em levantamento bibliográfico e documental, acompanhado de catalogação e análise crítica do material selecionado. A metodologia adotada inclui levantamento, sistematização e análise qualitativa dos acórdãos do Supremo Tribunal Federal relativos às ações judiciais que questionavam a constitucionalidade de diversos dispositivos do novo Código Florestal. Ao declarar a constitucionalidade da grande maioria das alterações da Lei 12.651/2012, o Supremo Tribunal Federal confirmou e consolidou um conjunto de retrocessos normativos em matéria de meio ambiente, esvaziando de modo substancial a orientação do princípio da vedação ao retrocesso socioambiental. 


\section{DIREITO AMBIENTAL E O PRINCÍPIO DA VEDAÇÃO AO RETROCESSO SOCIOAMBIENTAL}

Durante a fase de aperfeiçoamento do Direito Ambiental brasileiro, houve, primeiramente, a passagem de um momento de laissez-faire absoluto, para uma fase fragmentária, na qual apenas os microbens ambientais estariam relativamente protegidos. Em seguida, passou-se para uma fase holística, na qual a proteção do meio ambiente se daria de forma integral, a partir de uma perspectiva sistêmica. Entretanto, não basta que essa evolução no tratamento das questões ambientais apareça apenas na letra da lei; a implementação da legislação ambiental é crucial para a efetiva proteção do meio ambiente, posto que o Direito Ambiental é disciplina finalista, tendo em si uma obrigação de resultado (BENJAMIN, 2001, p. 2). A formulação da lei não é nada mais que o ponto de partida, o momento inicial de sua trajetória, que "pode ser curta ou longa, tranquila ou tumultuada, cara ou barata, democrática ou autoritária, efetiva ou inoperante, mas sempre prisioneira da sua implementação" (BENJAMIN, 2010, p. 5-6)

Um Estado no qual as leis existem apenas no papel pode ser considerado apenas "teatral", sendo a teatralidade estatal reconhecida sempre que se está diante de um "Poder Público que, na letra fria do texto normativo, não se importa em bravejar, mas que fácil e rapidamente amansa diante das dificuldades da realidade político-administrativa e de poderosos interesses econômicos, exatamente os maiores responsáveis pela degradação ambiental" (BENJAMIN, 2010, p. 6-7).

Este descompasso entre a norma escrita e a norma praticada impõe a adoção de medidas consistentes voltadas à efetiva aplicação da legislação ambiental. Todavia, se durante algum tempo a implementação era o principal obstáculo para a efetividade das normas ambientais, deve-se reconhecer que, atualmente, o foco está no enfrentamento do flagrante retrocesso - e ameaças de retrocessos - que se tem observado no contexto jurídico-ambiental nacional.

Pode-se considerar que o início da fase de retrocesso se deu com a edição da Lei de Biossegurança (Lei 11.105/2005), que, ao pretender estabelecer normas de segurança e mecanismos de fiscalização das atividades envolvendo organismos geneticamente modificados, flexibilizou e enfraqueceu as regras relativas ao tema. ${ }^{5}$ A referida lei é considerada o primeiro exemplo de diminuição de parâmetros legais

\footnotetext{
${ }^{5}$ A Lei 11.105/2005 substituiu a Lei 8.974/1995, que dispunha anteriormente sobre normas de segurança e mecanismos de fiscalização de atividades envolvendo organismos geneticamente modificados (OGM). Dentre os
} 
de proteção do meio ambiente até então consolidados, em flagrante descumprimento do princípio da vedação ao retrocesso socioambiental.

O Estado teatral pensado por Benjamin (2010), no qual há um vácuo ou descompasso entre a lei e sua implementação, é, atualmente, ainda mais complexo. Não se trata mais de um teatro, onde há apenas uma encenação, caracterizada pela ausência de aplicação prática da lei, mas de um cenário real, como numa arena de gladiadores, em que a tragédia não é apenas encenada; há, de fato, uma afronta direta ao arcabouço jurídico-ambiental consolidado. Nessa arena, os prejuízos socioambientais são reais e concretos, tanto do ponto de vista jurídico, quanto prático. Sendo assim, torna-se necessária e urgente a mobilização e densificação do princípio da vedação ao retrocesso socioambiental como forma de combater essa nova realidade de investidas desinibidas contra o Direito Ambiental brasileiro.

Discutido mundialmente, o princípio da vedação ao retrocesso socioambiental visa a garantir que o nível de proteção alcançado pelos direitos socioambientais não seja reduzido. No caso do Direito Ambiental, busca a proteção do direito fundamental ao meio ambiente ecologicamente equilibrado, positivado no caput do artigo 225 da Constituição como típico direito de terceira dimensão, transindividual, de titularidade indefinida ou indeterminável e plenamente reconhecido pela jurisprudência do Supremo Tribunal Federal. ${ }^{6}$

principais retrocessos promovidos pela nova Política Nacional de Biossegurança, destacam-se: (i) a simplificação dos processos decisórios sobre atividades envolvendo OGMs, enfraquecendo as normas de segurança vigentes; (ii) definição de competência da CTNBio para deliberar, em última e única instância, sobre a necessidade do licenciamento ambiental para a liberação no meio ambiente de OGMs; (iii) condicionamento do licenciamento ambiental somente quando o OGM for potencialmente causador de significativa degradação do meio ambiente, em flagrante desconformidade com o $\S 10$, inciso IV, do art. 225 da Constituição Federal, que dispõe sobre a exigência de Estudo Prévio de Impacto Ambiental (EIA/Rima) e não se confunde com a necessidade de licenciamento ambiental de atividades potencialmente poluidoras. Duas Ações Diretas de Inconstitucionalidade foram propostas pelo então Procurador-Geral da República, Claudio Fonteles. A primeira, ADI 3.510, impugnava o artigo 5o da Lei 11.105/2005, que estabelecia regras sobre a utilização de células-tronco embrionárias para fins de pesquisa e terapia. O Supremo Tribunal Federal decidiu, em maio de 2008 , que as pesquisas não violam o direito à vida ou a dignidade da pessoa humana, entendendo que a lei não mereceria reparo quanto ao dispositivo impugnado. A segunda ação judicial, a ADI 3.526, impugnava os seguintes dispositivos da Lei de Biossegurança: inciso VI do artigo 60; artigo 10; incisos IV,

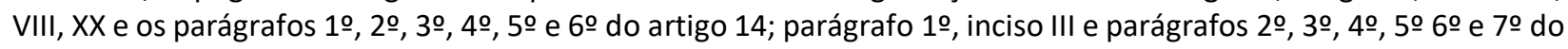
artigo 16; além dos artigos 30,34, 35, 36, 37 e 39; que referem-se à afronta à competência comum dos Entes Federados e sua independência na proteção do meio ambiente e afronta ao artigo 225 da Constituição Federal; no mérito, pedia que o STF declarasse a inconstitucionalidade de todos os dispositivos impugnados. Esta ação ainda está tramitando junto ao STF e desde outubro de 2009 encontra-se sem andamento.

${ }^{6}$ Sobre este assunto, vale conferir FENSTERSEIFER, 2008, p. 149 e o julgamento do Mandado de Segurança 22.164, em 1995, em cuja emente lê-se (BRASIL, 1995): “O direito à integridade do meio ambiente - típico direito de terceira geração - constitui prerrogativa jurídica de titularidade coletiva, refletindo, dentro do processo de afirmação dos 
É nesse contexto constitucional vigente de garantia dos direitos humanos de terceira geração, embasados em sólida doutrina e jurisprudência, que se faz necessário abordar a questão do núcleo essencial do direito fundamental ao meio ambiente ecologicamente equilibrado, que exige um mínimo de eficácia normativa (FENSTERSEIFER, 2008, p. 182) e, também, impõe um limite constitucional a modificações retrocessivas na legislação ambiental brasileira (CANOTILHO, 2003, p. 458).

Inspirado em constituições europeias, como a alemã de 1949, o núcleo essencial do direito fundamental é uma construção teórica que visa à proteção de um eixo intangível, para que as leis tenham efetividade real e não sejam aplicadas apenas sob o viés da legalidade, ou seja, para que possuam um conteúdo intrínseco que não pode ser violado. Por meio dele, as normas infraconstitucionais ficam vinculadas ao conteúdo material do princípio, impondo limites ao poder de transformação do legislador infraconstitucional. Frise-se que tal núcleo não representa um entrave à atividade legislativa, mas funciona como uma proteção à supremacia dos direitos fundamentais e ao seu conteúdo essencial (FENSTERSEIFER, 2008, p. 182 e 222).

A Constituição Federal de 1988 não prevê explicitamente a proteção do núcleo essencial dos direitos fundamentais. Entretanto, o artigo 60, parágrafo 4으, dispõe sobre a impossibilidade de emenda tendente a abolir direitos e garantias individuais; dispositivo que, associado ao direito fundamental ao meio ambiente ecologicamente equilibrado, previsto no artigo 225 , torna inequívoco o dever de proteção do núcleo essencial do direito fundamental ao meio ambiente ecologicamente equilibrado. Assim, a partir do conceito de núcleo essencial do direito fundamental ao meio ambiente, associado ao dever-poder de proteção ambiental por parte do Poder Público, funda-se o princípio jurídico da proibição de retrocesso socioambiental.

Veja-se, ainda, que os direitos humanos devem ser garantidos de forma progressiva, tendo em vista a melhoria da qualidade de vida e do meio ambiente per se. Essa orientação pode ser encontrada

direitos humanos, a expressão significativa de um poder atribuído, não ao indivíduo identificado em sua singularidade, mas num sentido verdadeiramente mais abrangente, à própria coletividade social. Enquanto os direitos de primeira geração (civis e políticos) - que compreendem as liberdades clássicas, negativas ou formais realçam o princípio da liberdade e os direitos de segunda geração (direitos econômicos, sociais e culturais) - que se identificam com as liberdades positivas, reais ou concretas - acentuam o princípio da igualdade, os direitos de terceira geração, que materializam poderes de titularidade coletiva atribuídos genericamente a todas as formações sociais, consagram o princípio da solidariedade e constituem um momento importante no processo de desenvolvimento, expansão e reconhecimento dos direitos humanos, caracterizados, enquanto valores fundamentais indisponíveis, pela nota de uma essencial inexauribilidade". 
em diversos documentos internacionais sobre o assunto, como o Pacto Internacional sobre Direitos Econômicos, Sociais e Culturais, ratificado pelo Brasil (BRASIL, 1992); ${ }^{7}$ a Declaração Universal dos Direitos Humanos (ONU, 1948); ${ }^{8}$ o Protocolo de São Salvador (BRASIL, 1999), ${ }^{9}$ adicional à Convenção Americana sobre Direitos Humanos em matéria de Direitos Econômicos, Sociais e Culturais; a Declaração de Estocolmo (ONU, 1972), ${ }^{10}$ dentre outros.

Internamente, a Lei 6.938/1981 dispõe que a "preservação, melhoria e recuperação da qualidade ambiental propícia à vida" (BRASIL, 1981, artigo 2º é objetivo geral da Política Nacional do Meio Ambiente, adotando de modo explícito uma visão de progressividade do Direito Ambiental. Portanto, além de aumentar gradualmente os níveis de proteção e proporcionar padrões de qualidade ambiental cada vez mais protetivos, não faz sentido pensar em progresso sem a garantia de que um patamar mínimo de cuidado com o meio ambiente seja assegurado e mantido com perenidade.

O reconhecimento do núcleo essencial dos direitos socioambientais garante a proteção desse mínimo, que pode ser chamado de mínimo existencial ecológico (SARLET; FENSTERSEIFER, 2017, p. 6). É o mínimo existencial ecológico que o princípio da vedação ao retrocesso busca proteger; por isso considera-se que este princípio, embora não garanta necessariamente o progresso, caminha ao seu lado como uma espécie de trava contra medidas retrocessivas (PRIEUR, 2012, p. 14). ${ }^{11}$ Assim, o princípio da vedação ao retrocesso socioambiental visa, no plano legislativo, a impedir que leis sejam revogadas ou

\footnotetext{
${ }^{7} \mathrm{O}$ artigo 20 do Pacto Internacional sobre Direitos Econômicos, Sociais e Culturais, de 16 de Dezembro de 1966, dispõe que: "Cada Estado Parte do presente Pacto compromete-se a adotar medidas, tanto por esforço próprio como pela assistência e cooperação internacionais, principalmente nos planos econômico e técnico, até o máximo de seus recursos disponíveis, que visem a assegurar, progressivamente, por todos os meios apropriados, o pleno exercício dos direitos reconhecidos no presente Pacto, incluindo, em particular, a adoção de medidas legislativas" (BRASIL, 1992).

8 Lê-se no Preâmbulo da Declaração Universal dos Direitos Humanos, de 10 de dezembro de 1948, o seguinte: "Considerando que os povos das Nações Unidas reafirmaram, na Carta, sua fé nos direitos fundamentais do ser humano, na dignidade e no valor da pessoa humana e na igualdade de direitos do homem e da mulher e que decidiram promover o progresso social e melhores condições de vida em uma liberdade mais ampla[...]" (ONU, 1948). ${ }^{9}$ Nos termos do artigo 11 do Protocolo de San Salvador, de 17 de novembro de 1988: "Direito a um meio ambiente sadio 1. Toda pessoa tem direito a viver em meio ambiente sadio e a dispor dos serviços públicos básicos. 2. Os Estados-Partes promoverão a proteção, preservação e melhoramento do meio ambiente" (BRASIL, 1999).

${ }^{10} \mathrm{O}$ artigo 2ㅇ da Declaração de Estocolmo, de 5 a 16 de junho de 1972, dispõe que: "A proteção e o melhoramento do meio ambiente humano é uma questão fundamental que afeta o bem-estar dos povos e o desenvolvimento econômico do mundo inteiro, um desejo urgente dos povos de todo o mundo e um dever de todos os governos" (ONU, 1972).

${ }^{11}$ Michel Prieur menciona as diversas nomenclaturas que o princípio da vedação ao retrocesso recebe em diferentes línguas, tais como: "stand still"; "cliquet anti-retour"; "eternity clause"; "prohibición de regressividade", etc. O autor escolher utilizar o termo "princípio de não regressão" (PRIEUR, 2012, p. 13-14).
} 
alteradas para diminuir padrões de qualidade ambiental essenciais já alcançados e positivados no ordenamento jurídico.

Ao julgar casos relativos a direitos fundamentais de caráter social, o STF (BRASIL, 2011) já se pronunciou afirmando que o "princípio da proibição do retrocesso impede [...] que sejam desconstituídas as conquistas já alcançadas pelo cidadão ou pela formação social em que ele vive” e, assim, “[...] traduz, no processo de efetivação desses direitos fundamentais individuais ou coletivos, obstáculo a que os níveis de concretização de tais prerrogativas, uma vez atingidos, venham a ser ulteriormente reduzidos ou suprimidos pelo Estado". Neste mesmo sentido, em julgado sobre a redução dos limites de unidade de conservação por medida provisória (BRASIL, 2018), afirmou-se que o "princípio da proibição de retrocesso socioambiental decorre diretamente do princípio da proibição de retrocesso social", impedindo "que o núcleo essencial dos direitos sociais já realizado e efetivado por medidas legislativas seja simplesmente aniquilado por medidas estatais".

Mais recentemente, já em julgado posterior ao acordão objeto de análise neste artigo (BRASIL, 2020), relativo a flexibilizações na regulamentação sobre controle e fiscalização de agrotóxicos, o STF partiu da premissa de que, segundo o princípio da proibição do retrocesso socioambiental, diante do "mínimo existencial socioambiental", "sem que se iniba a relativa margem de discricionariedade ínsita à ação legislativa e administrativa em matéria ambiental, não se mostra admissível permitir que se vulnere o núcleo essencial do direito fundamental ao meio ambiente ecologicamente equilibrado, previsto no art. 225 da Constituição da República”. (BRASIL, 2020)

É com base, portanto, na orientação do princípio da vedação do retrocesso socioambiental que se deve analisar as principais características da proteção florestal no Brasil, em especial as mudanças trazidas pelo novo Código Florestal.

\section{PROTEÇÃO FLORESTAL NO BRASIL}

A proteção das florestas no Brasil teve início no período colonial, com uma visão ainda utilitarista do meio ambiente, visando apenas à proteção parcial dos denominados recursos ou bens ambientais. Assim, sob o viés econômico e de controle da extração de madeira, podem ser mencionados alguns 
exemplos históricos como a Carta Régia, de 1442, o Regimento do Pau Brasil, de 1605, e o primeiro Código Florestal brasileiro, instituído pelo Decreto 23.793/1934.

O Código Florestal de 1934 (Decreto 23.793/1934) foi editado em conjunto com diversas outras normas ambientais federais, influenciadas pela Constituição Federal promulgada no mesmo ano, que determinava a proteção das "belezas naturais" (BRASIL, 1934). Nesse contexto, foram aprovados também o Código de Minas (Decreto-Lei 1.985/1940), o Código de Caça e Pesca (Decreto-Lei 5.894/1943), o Código de Águas (Decreto 24.643/1934), além do próprio Código Florestal, cujo objetivo "era essencialmente produtivista, classificando a maior parte das florestas do país como 'de rendimento' e colocando, como modelo de floresta, a 'silvicultura ordenada e produtiva'” (LIMA; BENSUSAN; RUSS, 2014, p. 9). Já naquele momento, observa-se a preocupação com a preservação de áreas não desmatadas no interior de grandes propriedades privadas, prevendo a obrigação de manutenção de $25 \%$ da propriedade preservados, além da preocupação com as florestas "protetoras" e "remanescentes", que viriam a se tornar as atuais Áreas de Preservação Permanente (APP) e de Reserva Legal (RL).

Em 1965, entrou em vigor o segundo Código Florestal brasileiro (Lei 4.771/1965), revogado em 2012 pela atual legislação federal sobre florestas (Lei 12.651/2012). O Código Florestal de 1965 foi o primeiro a apresentar uma preocupação com "a manutenção do ciclo hidrológico, com a degradação do solo, em consequência do modo de produção, com as enchentes anormais, com os processos de desertificação e com a futura escassez dos recursos naturais" (LIMA; BENSUSAN; RUSS, 2014, p. 9). Foi também o responsável pela proteção de áreas sensíveis e que desempenham importantes funções ambientais, as Áreas de Preservação Permanente (APP), e de biomas existentes no território nacional, mediante criação das áreas de Reserva Legal (RL).

Com o desenrolar da proteção das florestas e do meio ambiente de modo geral, houve a edição de normas importantes como a Lei da Política Nacional do Meio Ambiente (Lei 6.938/1981), a Lei de Crimes e Infrações Contra o Meio Ambiente (Lei 9.605/1998), e a própria Constituição Federal de 1988, cujo texto é considerado o primeiro verdadeiramente ecológico, com o Capítulo VI destinado especificamente para a matéria ambiental, inserido no Título VIII, referente à Ordem Social.

O artigo 225 da Constituição Federal positiva o direito fundamental ao meio ambiente ecologicamente equilibrado e implica, assim, toda uma nova interpretação da matéria, com vistas à proteção da dignidade da pessoa humana, tutelando o meio ambiente como um bem jurídico per se, ou 
seja, autônomo, e oponível erga omnes, consagrando, ainda, a "ética da solidariedade entre gerações" (MACHADO, 2014, p. 155). O legislador primário preocupou-se, ainda, em garantir a proteção dos espaços territoriais especialmente protegidos (ETEP), assim como os processos e funções ecológicas por eles desempenhados, ao estabelecer dentre os deveres específicos do Poder Público para a efetividade do direito de todos ao meio ambiente equilibrado a definição de "espaços territoriais e seus componentes a serem especialmente protegidos" (artigo 225, parágrafo 1으, CF/1988). A este respeito, no processo de evolução das normas do Direito Ambiental, pode-se mencionar a importância, em conjunto com o Código Florestal, da Lei Federal 9.985/2000, que institui o Sistema Nacional de Unidades de Conservação (SNUC).

Diante do cenário de desenvolvimento e reforço contínuo do arcabouço jurídico-ambiental, houve um gradual e consequente aumento da fiscalização das atividades relacionadas ao meio ambiente, incluindo-se aí uma tentativa de aplicação mais eficiente também do Código Florestal de 1965, o que acabou desencadeando um processo de revisão do mesmo com vista a "afrouxá-lo", corporificado pelo Projeto de Lei 1.876/1999, de autoria do deputado Aldo Rebelo.

Em 2012 foi sancionada a Lei 12.651, a despeito de vasta manifestação popular e dos principais grupos científicos no país contra sua aprovação, enfraquecendo de modo significativo instrumentos como a Reserva Legal (RL) e as Áreas de Preservação Permanente (APP).

A terceira e mais recente lei florestal do país (Lei 12.651/2012) (2) $^{12}$ resultou de um processo legislativo conturbado, de muitas críticas por parte da sociedade civil e da comunidade científica. ${ }^{13}$ Também foi alvo de Ações Diretas de Inconstitucionalidade ajuizadas pela Procuradoria-Geral da República (ADIs 4.901, 4.902 e 4.903) e pelo Partido Socialismo e Liberdade (PSOL) (ADI 4937). O julgamento destas ações pelo Supremo Tribunal Federal (STF) teve início em 17 de setembro de 2017 e foi concluído em 28 de fevereiro do 2018 (BRASIL, 2019b, 2019c, 2019d, 2019e).

\footnotetext{
${ }^{12}$ Deve ser analisada em conjunto com o Decreto federal 7.830/2012, que dispõe sobre o Cadastro Ambiental Rural e os Programas de Regularização Ambiental, novos instrumentos previstos no Código Florestal atual; o Decreto federal 8.265/2014, que estabelece regras complementares aos Programas de Regularização da nova lei; e a Instrução Normativa 2/2014 do Ministério do Meio Ambiente, que dispõe sobre os procedimentos do Cadastro Ambiental Rural a nível federal.

${ }^{13}$ Cumpre mencionar duas importantes publicações que buscaram auxiliar o processo de alteração do Código Florestal de 1965, fornecendo dados científicos sobre a matéria em discussão e demonstrando os perigos da diminuição dos parâmetros de proteção vigentes até então: LIMA, BENSUSAN, RUSS, 2014; e SOCIEDADE..., 2011.
} 
Fato é que o novo Código Florestal traz inúmeros retrocessos, dentre os quais se destacam o marco temporal criado pela construção do conceito de área rural consolidada - e suas consequências - $^{14}$ e as flexibilizações relativas aos parâmetros aplicáveis às APPs e RLs.

A área rural consolidada, definida no artigo 3o, inciso IV, da Lei 12.651/2012, ${ }^{15}$ é a área ocupada irregularmente entre a entrada em vigor do Código Florestal de 1965 e o marco temporal de 22 de julho de 2008, que coincide com a edição do Decreto 6.514/2008, que regulamenta as infrações e sanções administrativas ao meio ambiente previstas na Lei $9.605 / 1998 .{ }^{16}$

${ }^{14} \mathrm{Em}$ decorrência da criação das áreas rurais consolidadas, muitos outros retrocessos foram inseridos no atual Código Florestal (BRASIL, 2012a), tais como: (i) considerar de interesse social a implantação de infraestrutura pública destinada a esportes, lazer e atividades educacionais e culturais ao ar livre em áreas urbanas e rurais consolidadas (art. 3ำ, IX, "c") (ii) permitir a utilização dos apicuns e salgados em áreas consolidadas (art. 11-A, §1ㅇ, I, e §6o); (iii) permitir a redução, exclusivamente para fins de regularização, mediante recomposição, regeneração ou compensação da Reserva Legal de imóveis com área rural consolidada, situados em área de floresta localizada na Amazônia Legal, para até 50\% (cinquenta por cento) da propriedade, excluídas as áreas prioritárias para conservação da biodiversidade e dos recursos hídricos e os corredores ecológicos (art. 13, 1); (iv) considerar regularizadas, mediante assinatura do termo de compromisso constante no Programa de Regularização Ambiental (PRA), as áreas rurais consolidadas (art. 59, §5ㅇ); (v) permitir a continuidade das atividades agrossilvipastoris, de ecoturismo e de turismo rural em áreas rurais consolidadas em áreas de preservação permanente (61-A, caput); (vi) permitir, nas faixas marginais de cursos d'água, entorno de nascentes e olhos d'água e veredas, a recuperação em parâmetros inferiores aos previstos pelo Código Florestal de 1965 (art. 61-A, §§1으 a 70); (vii) admitir a manutenção de atividades florestais, culturas de espécies lenhosas, perenes ou de ciclo longo, bem como da infraestrutura física associada ao desenvolvimento de atividades agrossilvipastoris, vedada a conversão de novas áreas para uso alternativo do solo, nas áreas consolidadas em encostas ou partes destas com declividade superior a $45^{\circ}$, equivalente a $100 \%$ (cem por cento) na linha de maior declive; bordas dos tabuleiros ou chapadas, até a linha de ruptura do relevo, em faixa nunca inferior a 100 (cem) metros em projeções horizontais; topo de morros, montes, montanhas e serras, com altura mínima de 100 (cem) metros e inclinação média maior que $25^{\circ}$, as áreas delimitadas a partir da curva de nível correspondente a $2 / 3$ (dois terços) da altura mínima da elevação sempre em relação à base, sendo esta definida pelo plano horizontal determinado por planície ou espelho d'água adjacente ou, nos relevos ondulados, pela cota do ponto de sela mais próximo da elevação e as áreas em altitude superior a 1.800 (mil e oitocentos) metros, qualquer que seja a vegetação (art. 63, caput); (viii) permitir a regularização de área de Reserva Legal em extensão inferior ao estabelecido no art. 12, mesmo sem adesão ao PRA, mediante adoção de uma de recomposição, regeneração natural ou compensação (art. 66, caput, I, II e III); (ix) permitir a manutenção de percentuais inferiores ao previsto para as áreas de Reserva Legal, nos casos de área rural consolidada em propriedades inferiores a quatro módulos fiscais (art. 67); (x) dispensar a obrigação de recomposição, compensação ou regeneração para proprietários ou possuidores de imóveis rurais que realizaram supressão de vegetação nativa respeitando os percentuais de Reserva Legal previstos pela legislação em vigor à época (art. 68).

${ }^{15} \mathrm{O}$ artigo 3ㅇ, IV, Lei 12.651/ 2012, conceitua: “Área rural consolidada: área de imóvel rural com ocupação antrópica preexistente a 22 de julho de 2008, com edificações, benfeitorias ou atividades agrossilvipastoris, admitida, neste último caso, a adoção do regime de pousio" (BRASIL, 2012a).

16 RODRIGUES (2013, p. 350-352) defende que, mesmo antes da publicação do Decreto Federal 6.514/2008 (regulamenta, atualmente, as infrações contra o meio ambiente com base na Lei 9.605/1998), ocorrida em 22 de julho de 2008, "não havia óbices legais para que o poder de polícia repressivo fosse aplicado àqueles que cometiam infrações administrativas por agressão a Áreas de Preservação Permanente e de Reserva Legal (...)", tendo em vista que o referido ato regulamentar é "o segundo decreto regulamentador da Lei 9.605/1998, de forma que desde o 
A definição das áreas rurais consolidadas e das regras a elas aplicáveis acabou por criar dois regimes jurídicos distintos relativos às Áreas de Preservação Permanentes (APPs) e às Reservas Legais (RLs), o que, por si só já configura um retrocesso e afronta o princípio da isonomia. Se, em geral, as APPs submetem-se às regras dispostas no Capítulo II da Lei 12.651/2012 (artigos 4ㅇao 9ㅇ) e as RLs ao previsto no Capítulo IV (artigos 12 ao 25), em áreas consideradas consolidadas o regime de proteção das APPs e das RLs é diferente, bem mais flexível e menos restritivo, beneficiando exatamente aqueles proprietários que descumpriram a lei florestal até julho de 2008 (Capítulo XIII, Disposições Transitórias, artigos 61-A ao 68).

Repita-se, inexplicável e ironicamente, os parâmetros de proteção são mais flexíveis exatamente para aqueles que sempre descumpriram a lei anterior e desmataram os referidos espaços protegidos. E, por outro lado, aqueles que sempre respeitaram as restrições à supressão de vegetação em APP e em RL já previstas na legislação anterior continuam submetidos a parâmetros mais rigorosos, o que gera insegurança jurídica e desrespeito ao princípio da isonomia.

A nova lei criou, também, o Cadastro Ambiental Rural (CAR), um registro público autodeclaratório, online e obrigatório a todos os imóveis rurais, que dispensou a averbação em cartório prevista na lei anterior. ${ }^{17}$ Mediante a adesão ao CAR e identificação das áreas consolidadas e dos espaços territoriais a serem especialmente protegidos, o proprietário ou possuidor poderá aderir aos Programas de Regularização Ambiental e ser desobrigado do pagamento das multas e da punibilidade dos crimes

anterior [Decreto 3.179/1999] já se poderia aplicar as sanções administrativas ambientais por infrações cometidas contra a Reserva Legal e Área de Preservação Permanente (...)".

${ }^{17}$ Cf. artigos 29 e 30 da Lei 12.651/2012. 
previstos nos artigos 38, 39 e 40 da Lei $9.605 / 1998,{ }^{18}$ além de não poder ser autuado por infrações cometidas antes do marco temporal. ${ }^{19} 20$

Com relação às APPs, elas podem estar localizadas em áreas urbanas ou rurais e protegem (i) as faixas marginais de qualquer curso d'água natural perene e intermitente, excluídos os efêmeros, desde a borda da calha do leito regular; (ii) as áreas no entorno dos lagos e lagoas naturais; (iii) as áreas no entorno dos reservatórios d'água artificiais, decorrentes de barramento ou represamento de cursos d'água naturais; (iv) as áreas no entorno das nascentes e dos olhos d'água perenes; (v) as encostas ou partes destas com declividade superior a 45ㅇ; (vi) as restingas; (vii) os manguezais; (viii) as bordas dos tabuleiros

\footnotetext{
18 Nos termos dos artigos 38, 39 e 40 da Lei 9.605/1998:

“Art. 38. Destruir ou danificar floresta considerada de preservação permanente, mesmo que em formação, ou utilizála com infringência das normas de proteção:

Pena - detenção, de um a três anos, ou multa, ou ambas as penas cumulativamente. Parágrafo único. Se o crime for culposo, a pena será reduzida à metade.

Art. 38-A. Destruir ou danificar vegetação primária ou secundária, em estágio avançado ou médio de regeneração, do Bioma Mata Atlântica, ou utilizá-la com infringência das normas de proteção:

Pena - detenção, de 1 (um) a 3 (três) anos, ou multa, ou ambas as penas cumulativamente.

Parágrafo único. Se o crime for culposo, a pena será reduzida à metade.

Art. 39. Cortar árvores em floresta considerada de preservação permanente, sem permissão da autoridade competente:

Pena - detenção, de um a três anos, ou multa, ou ambas as penas cumulativamente.

Art. 40. Causar dano direto ou indireto às Unidades de Conservação e às áreas de que trata o art. 27 do Decreto no 99.274, de 6 de junho de 1990, independentemente de sua localização:

Pena - reclusão, de um a cinco anos.

$\S 1$ 을 Entende-se por Unidades de Conservação de Proteção Integral as Estações Ecológicas, as Reservas Biológicas, os Parques Nacionais, os Monumentos Naturais e os Refúgios de Vida Silvestre.

§ 2ㅇ A ocorrência de dano afetando espécies ameaçadas de extinção no interior das Unidades de Conservação de Proteção Integral será considerada circunstância agravante para a fixação da pena.

§ 30 Se o crime for culposo, a pena será reduzida à metade" (BRASIL, 1998).

${ }^{19}$ Cf. artigos 59 e 60, Lei 12.651/2012.

${ }^{20}$ A inscrição do imóvel rural no Cadastro Ambiental Rural (CAR) é condição obrigatória para a adesão ao Programa de Regularização Ambiental (PRA), de acordo com o artigo 59 do Código Florestal. No entanto, desde a sua publicação, no ano de 2012, o prazo para adesão ao CAR vendo sendo reiteradamente prorrogado. Atualmente, de acordo com a Lei 13.887/2019, o prazo para adesão ao CAR é 31 de dezembro de 2020. É importante frisar que, muito embora a lei em comento trate apenas da extensão de prazo para adesão ao PRA, diversas Medidas Provisórias sobre o tema e suas respectivas emendas foram editadas entre 2012 e 2019, cujo conteúdo ultrapassava, em alguns casos, a pertinência temática com o objeto das Medidas Provisórias. De acordo com Nota Técnica divulgada pelo Climate Policy Initiative, das 35 emendas propostas no âmbito da Medida Provisória 867/2018, 5 não possuíam qualquer relação com o objeto da Medida Provisória e 35 extrapolavam seu objeto. As emendas propostas tratam das regras relativas ao PRA e ao termo de compromisso; da aplicação da lei no tempo com relação à reserva legal e da reposição florestal obrigatória (CHIAVARI e LOPES, 2019).
} 
ou chapadas; (ix) os topos de morros, montes, montanhas e serras; ( $\mathrm{x}$ ) as áreas em altitude superior a 1.800 (mil e oitocentos) metros; e (xi) as veredas. ${ }^{21}$

As Ações Diretas de Inconstitucionalidade em comento foram propostas com fundamento constitucional no dever geral de não degradação do meio ambiente, além dos deveres específicos do Estado de assegurar a efetividade do direito ao meio ambiente ecologicamente equilibrado. Considerouse que o regime de proteção dos espaços territoriais especialmente protegidos e o dever de preservação e restauração dos processos ecológicos essenciais foram violados, em desrespeito ao previsto no artigo 225, parágrafo 1ำ, incisos I e III, da Constituição Federal. ${ }^{22}$ Isso porque a proteção de tais espaços articulase diretamente com a "preservação da diversidade e integridade do patrimônio genético do País, bem como da proteção da fauna e da flora" (Brasil, 2019b, p. 11). As petições iniciais das Ações Diretas de Inconstitucionalidade propostas pela Procuradoria-Geral da República (ADI 4.901, ADI 4.902 e ADI 4.903) mencionam que as inconstitucionalidades encontradas no Código Florestal de 2012 decorrem da afronta a dispositivos legais relativos aos espaços territoriais especialmente protegidos, especialmente no que toca aos deveres do Poder Público, mediante fragilização do regime de proteção das Áreas de Preservação permanente (APP) e Reservas Legais (RL). Com isso, reconhece-se que "[a]lém de afrontar os deveres fundamentais, as normas impugnadas violam o princípio da vedação ao retrocesso social, pois, de forma geral, estabelecem um padrão de proteção ambiental manifestamente inferior ao anteriormente existente" (BRASIL, 2019b, p. 13).

Com relação às APPs, as seguintes inconstitucionalidades na Lei 12.651/2012 podem ser suscitadas: (i) permissão de novos desmatamentos sem que haja recuperação dos já realizados irregularmente (artigo 7ำ, parágrafo 3ํ); (ii) retrocesso quanto à largura das faixas de proteção das áreas de preservação permanente dos cursos d'água em razão das mudanças nos parâmetros de medição (artigos 3ํ, XIX, e 4ํ, I); (iii) legalização de danos ambientais decorrentes de infrações à legislação de proteção às áreas de preservação permanentes praticadas até 22 de julho de 2008 (artigos 61-A, 61-B, 61-

\footnotetext{
${ }^{21}$ Cf. artigo 3ㅇ, II, e 4ㅇ da Lei 12.651/2012.

22 Nos termos do artigo 225 da Constituição Federal (BRASIL, 1988): "Todos têm direito ao meio ambiente ecologicamente equilibrado, bem de uso comum do povo e essencial à sadia qualidade de vida, impondo-se ao Poder Público e à coletividade o dever de defendê-lo e preservá-lo para as presentes e futuras gerações. §1으 Para assegurar a efetividade desse direito, incumbe ao Poder Público: I - preservar e restaurar os processos ecológicos essenciais e prover o manejo ecológico das espécies e ecossistemas; [...] III - definir, em todas as unidades da Federação, espaços territoriais e seus componentes a serem especialmente protegidos, sendo a alteração e a supressão permitidas somente através de lei, vedada qualquer utilização que comprometa a integridade dos atributos que justifiquem sua proteção; [...]".
} 
C e 63); (iv) flexibilizações relativas às intervenções em áreas de preservação permanente na hipótese de utilidade pública e interesse social (artigo 3ํ, VIII e IX, artigo 4으, parágrafos 6ㅇe e 8으); (v) previsão normativa acerca das atividades de aquicultura em área de preservação permanente (artigo 4으, parágrafo 6으); (vi) intervenções em mangues e restingas (artigo 8oㅡ, parágrafo 2ํ); (vii) uso agrícola das várzeas (artigo 4으, parágrafo 5ㅇ); (viii) diminuição da proteção das nascentes e olhos d'água (artigo 2o, "c"); (ix) diminuição da proteção da áreas de preservação permanente em reservatórios artificiais (artigo 2o, "b", artigo 4으, parágrafos 1으 e 4으, artigo 5ㅇ); e (x) diminuição da proteção das áreas com inclinação entre 25ㅇ e 45으 (artigo 10).

Dentre os vários retrocessos trazidos pela Lei 12.651/2012, merece destaque o relativo às APPs ao longo de cursos d'água nos imóveis rurais consolidados. Nestes casos, além da redução em si dos parâmetros das APPs, quando comparados aos aplicáveis às áreas consideradas "não consolidadas", a definição das metragens a serem preservadas em caráter permanente dar-se-á com base no tamanho da propriedade na qual está inserida, calculada em módulos fiscais, ${ }^{23}$ sem nenhuma conexão com a largura do curso d'água a ela relacionado ou com as características naturais, de relevo ou topográficas do local em que estejam inseridas, o que desconsidera por completo as funções ambientais a serem desempenhadas por estes espaços protegidos, prejudicando, por exemplo, o endemismo das espécies que abrigam e a formação de corredores ecológicos. ${ }^{24}$

Apenas para ilustrar o contrassenso citado, veja-se que o menor parâmetro aplicável, como regra geral, às APPs determina a largura de 30 metros como faixa marginal a ser preservada ao longo de cursos d'água de menos de menos de 10 metros de largura. Por outro lado, se a área for considerada consolidada, o menor parâmetro de proteção será de ínfimos 5 metros de largura, para os casos de propriedades com áreas de até 1 modulo fiscal; parâmetro este aplicável independentemente da largura do rio, ou seja, inclusive para rios com mais de 600 metros de largura (que, demandariam, de acordo com a regra geral, a

\footnotetext{
${ }^{23}$ Módulos fiscais são unidades de medida definidas pelo INCRA e são estabelecidos de acordo com o município onde estão localizados. Medidos em hectares, podem variar de 5 a 110 hectares. 0 imóvel de até 4 (quatro) módulos fiscais, que recebe isenções e benefícios de acordo com o Código Florestal, pode representar uma propriedade de 20 ha até 440 ha. O que significa que, dependendo do município onde esteja localizado, um imóvel menor do que 4 (quatro) módulos fiscais pode corresponder a uma grande propriedade (informações disponíveis em: https://www.embrapa.br/codigo-florestal/area-de-reserva-legal-arl/modulo-fiscal. Acesso em 26 abr. 2019).

${ }^{24}$ Para identificação dos diferentes regimes jurídicos - e parâmetros - aplicáveis às APPs em geral e às APPs em áreas consolidadas, deve-se consultar, dentre outros, os artigos 4으 e 61-A.
} 
preservação de 500 metros de faixa marginal), de acordo com o artigo 61-A, parágrafo 1ำ da Lei 12.651/2012 (BRASIL, 2012a) e artigo 19, parágrafo 10 do Decreto 7.830/2012 (BRASIL, 2012b).

Outro exemplo de retrocesso está no fato de que, de acordo com o artigo 63 da Lei 12.651/2012, topos de morro, bordas de tabuleiro, encostas com declividade acima de 45 으 e regiões com altitude acima de 1.800 metros que se encaixem no conceito de área rural consolidada não precisarão recuperar a área, independentemente do tamanho do imóvel, tendo sido expressamente admitida a "manutenção de atividades florestais, culturas de espécies lenhosas, perenes ou de ciclo longo, bem como da infraestrutura física associada ao desenvolvimento de atividades agrossilvipastoris, vedada a conversão de novas áreas para uso alternativo do solo".

Já as Reservas Legais (RLs), definidas no artigo 3ำ, inciso III, da Lei $12.651 / 2012,{ }^{25}$ têm a função de proteger a vegetação nativa de determinado bioma, em áreas rurais, conforme porcentagens específicas legalmente estabelecidas. Na Amazônia Legal o percentual é de $80 \%$ em áreas de florestas, 35\% em áreas de cerrado e $20 \%$ em áreas de campos gerais e nas demais regiões do país. Deve-se ressaltar que o regime de proteção das RLs (= conservação) é diferente e menos restritivo do que o aplicável às APPs (= preservação), porque se trata de espaços protegidos diferentes, com funções igualmente distintas, admitindo-se nas RLs - mas, em regra, não nas APPs - a exploração econômica mediante manejo sustentável. ${ }^{26}$

Nas Ações Diretas de Inconstitucionalidade já referidas, foram suscitadas as seguintes inconstitucionalidades relativas ao regime de proteção das Reservas Legais (RLs): (i) possibilidade de redução da RL em virtude da existência de terras indígenas e unidades de conservação em determinadas circunstâncias (artigo 12, parágrafos 4으 e 5ㅇ); (ii) dispensa de constituição de RL por empreendimentos de abastecimento público de água e tratamento de esgoto ou por detentores de concessão ou autorização para explorar energia elétrica nas áreas adquiridas ou desapropriadas para implantação ou ampliação da capacidade de ferrovias e rodovias (artigo 12 , parágrafos $6^{\circ}$, 7ํ e $8^{\circ}$ ); (iii) permissão de instituição de servidão ambiental sobre o excedente de Reserva Legal fruto da diminuição de parâmetros na Amazônia

\footnotetext{
${ }^{25}$ Nos termos do artigo 3으, III, da Lei 12.651/2012, entende-se por: “Reserva Legal: área localizada no interior de uma propriedade ou posse rural, delimitada nos termos do art. 12, com a função de assegurar o uso econômico de modo sustentável dos recursos naturais do imóvel rural, auxiliar a conservação e a reabilitação dos processos ecológicos e promover a conservação da biodiversidade, bem como o abrigo e a proteção de fauna silvestre e da flora nativa" (BRASIL, 2012a).

${ }^{26} \mathrm{Cf}$. artigo 17 , § 1으, da Lei 12.651/2012.
} 
Legal, de acordo com o Zoneamento Ecológico Econômico (artigo 13, parágrafo 1ํ); (iv) autorização para cômputo de Áreas de Preservação Permanente no percentual de Reserva Legal (artigo 15); (v) permissão do plantio de espécies exóticas para recomposição da RL (artigo 66, parágrafo 3o); (vi) compensação da RL sem que haja identidade ecológica entre as áreas, e compensação por arrendamento ou pela doação de área localizada no interior de unidade de conservação a órgão do Poder Público (artigo 48, parágrafo $2^{\circ}$, e artigo 66, parágrafo 5, II, III e IV, e parágrafo 6ㅇ); (vii) consolidação das áreas desmatadas de acordo com a legislação em vigor à época do desmatamento (artigos 12 e 68, caput); e (viii) constituição de área de RL em percentuais inferiores aos aplicáveis em caráter geral e limitados ao tamanho da área coberta por vegetação nativa em 22 de julho de 2008, nos casos de imóveis rurais com área de até quatro módulos fiscais (artigo 67).

Com relação à Reserva Legal, vale mencionar o significativo retrocesso promovido pela legalização dos desmatamentos ocorridos em imóveis menores do que quatro módulos fiscais, que não precisarão recompor a vegetação, de acordo com o artigo 67 da Lei 12.651/2012. Apenas se houver algum percentual de RL remanescente é que este deverá ser preservado. Não havendo percentual algum, a lei dispensa os desmatadores da obrigação de recuperar os danos causados. É difícil deixar de reconhecer caráter inconstitucional e retrocessivo aos dispositivos que consolidam tal situação. Violam o artigo 225, parágrafos 1 , inciso III, 3 e 4ํㅡ da Constituição Federal, ${ }^{27}$ por ignorarem a obrigação de reparação dos danos ambientais causados e autorizarem a utilização de espaço protegido que acaba por comprometer os atributos que justificaram sua criação.

Outro exemplo de retrocesso trazido pela nova lei é a confusão dos conceitos de APP e RL mediante permissão de que a APP seja contabilizada dentro do percentual de RL, de acordo com o artigo 15 da Lei 12.651/2012. Isso significa que uma propriedade com APP cuja área seja igual ou superior ao percentual de RL exigido naquele bioma, não precisará manter área alguma a título de RL, o que anula por completo a função da RL, que é marcadamente diferente das funções da APP, e compromete os atributos

\footnotetext{
27 Nos termos do artigo 225, parágrafos 1으, inciso III, 3ำ e 4ำ da Constituição Federal: “§ 1 Para assegurar a efetividade desse direito, incumbe ao Poder Público: [...] III - definir, em todas as unidades da Federação, espaços territoriais e seus componentes a serem especialmente protegidos, sendo a alteração e a supressão permitidas somente através de lei, vedada qualquer utilização que comprometa a integridade dos atributos que justifiquem sua proteção; [...]. § 3 ㅇ As condutas e atividades consideradas lesivas ao meio ambiente sujeitarão os infratores, pessoas físicas ou jurídicas, a sanções penais e administrativas, independentemente da obrigação de reparar os danos causados. § 40 A Floresta Amazônica brasileira, a Mata Atlântica, a Serra do Mar, o Pantanal Mato-Grossense e a Zona Costeira são patrimônio nacional, e sua utilização far-se-á, na forma da lei, dentro de condições que assegurem a preservação do meio ambiente, inclusive quanto ao uso dos recursos naturais" (BRASIL, 1988).
} 
que justificaram sua proteção como espaço territorialmente protegido, indo de encontro mais uma vez ao princípio da vedação ao retrocesso e à Constituição Federal.

Ainda com relação à recomposição de Reserva Legal, as novas regras constantes da Lei 12.651/2012 (BRASIL, 2012a), em especial o artigo 22, inciso III, ${ }^{28}$ permitem o plantio intercalado de espécies vegetais nativas e exóticas sem prever que isso se dê de forma apenas transitória. Além disso, permite-se a compensação da RL dentro do mesmo bioma, de acordo com o artigo 66, parágrafo 6o, inciso II, enquanto na lei anterior essa compensação era autorizada apenas dentro da mesma micro-baciahidrográfica ou, no máximo, dentro da mesma bacia hidrográfica, de acordo com o artigo 44, parágrafo 4은 da Lei 4.771/1965 (BRASIL, 1965), o que fazia com que a compensação não ocorresse em local muito distante ou diverso daquele onde ocorreu o dano. Com a nova lei, considerando-se, por exemplo, o bioma amazônico, o dano pode ter acontecido no Pará e a compensação poderá ser realizada no Acre.

Os exemplos apresentados - haveria outros - demonstram que a função da Reserva Legal se encontra ao menos esvaziada na nova legislação, seja (i) pelos parâmetros menores de recuperação; (ii) pela não obrigatoriedade de reparação dos danos em determinados casos; ou (iii) pela confusão de espaços territoriais protegidos no que toca às suas respectivas funções. Todas essas situações demonstram retrocessos, na medida em que o nível de proteção uma vez alcançado pelo direito positivo foi significativamente diminuído, de modo a afetar diretamente o núcleo essencial do direito fundamental ao meio ambiente ecologicamente equilibrado.

Fica clara a intenção da nova lei de resolver, em favor do infrator, as questões dos passivos ambientais ocasionados por ocupações em desconformidade com o Código Florestal de 1965, provocando com isso inconstitucionalidades e retrocessos. Em passo típico de tempos que se supunha passados, foram privilegiados interesses privados - aliás, ao menos em parte, marcados por alto grau de ilicitude - em detrimento de interesses coletivos e de direitos constitucionalmente assegurados, em especial ao meio ambiente ecologicamente equilibrado, essencial à sadia qualidade de vida. Por tais motivos, o Código Florestal de 2012 foi questionado junto ao STF, como se passa a analisar.

\footnotetext{
${ }^{28}$ Nos termos do artigo 22 da Lei 12.651/2012: “O manejo florestal sustentável da vegetação da Reserva Legal com propósito comercial depende de autorização do órgão competente e deverá atender as seguintes diretrizes e orientações: [...] III - conduzir o manejo de espécies exóticas com a adoção de medidas que favoreçam a regeneração de espécies nativas" (BRASIL, 2012a).
} 


\section{O NOVO CÓDIGO FLORESTAL SOB A ÓTICA DO SUPREMO TRIBUNAL FEDERAL}

Em função das mudanças legislativas que, como visto, enfraqueceram de modo significativo a tutela jurídica dispensada às florestas e demais formas de vegetação, não é de se estranhar que a nova legislação florestal tenha sido alvo de quatro Ações Diretas de Inconstitucionalidade (ADIs), nas quais foram questionados diversos dispositivos da Lei 12.651/2012 relativos, em geral, às Áreas de Preservação Permanente, à redução da Reserva Legal e à anistia para degradadores ambientais.

Como já mencionado, trata-se das ADIs 4.901, 4.902, 4.903, 4.937, as três primeiras propostas pela Procuradoria-Geral da República e a última ajuizada pelo PSOL (Partido Socialismo e Liberdade). Já a Ação Declaratória de Constitucionalidade (ADC) 42, de autoria do PP (Partido Progressista) foi proposta em defesa da constitucionalidade da Lei 12.651/2012. Em 18/04/2016, questões técnicas relacionadas ao novo Código Florestal foram debatidas em audiência pública no Supremo Tribunal Federal (STF), da qual participaram pesquisadores, acadêmicos, representantes do governo federal, integrantes de movimentos sociais e produtores rurais. ${ }^{29}$ O Plenário do STF iniciou no dia 14/09/2017 o julgamento conjunto das referidas ações, sob a relatoria do Ministro Luiz Fux. ${ }^{30}$ A conclusão do julgamento ocorreu em 28/02/2018 e seus respectivos acórdãos foram publicados em 13/08/2019 (Brasil, 2019a, 2019b, 2019c, 2019d, 2019e). Passa-se, a seguir, à breve e não exaustiva apresentação e análise crítica dos principais resultados do referido julgamento. ${ }^{31}$

O posicionamento dos ministros do STF sobre cada uma das diversas inconstitucionalidades arguidas foi bastante heterogêneo, tendo o Tribunal Pleno, ao final do julgamento, reconhecido a validade de muitos dos dispositivos da Lei 12.651/2012 e declarado inconstitucionais apenas alguns dos seus trechos, além de ter atribuído interpretação conforme à Constituição a outros artigos.

\footnotetext{
${ }^{29}$ Sobre o assunto, conferir a seguinte notícia: STF realiza audiência pública sobre novo Código Florestal nesta segunda (18). Disponível em: http://www.stf.jus.br/portal/cms/verNoticiaDetalhe.asp?idConteudo=314459. Acesso em 22 abr. 2019.

30 Sobre o assunto, conferir a seguinte notícia: STF inicia julgamento de ações sobre o novo Código Florestal. Disponível em: http://www.stf.jus.br/portal/cms/verNoticiaDetalhe.asp?idConteudo=355704. Acesso em 22 set. 2017.

${ }^{31}$ Este artigo foi inicialmente redigido em momento anterior à publicação do Acórdão relativo às discussões sobre a constitucionalidade do Código Florestal, com base nos votos dos Ministros do STF e nas notícias publicadas no site deste. Após a publicação do Acórdão foi realizada atualização e verificação das informações mencionadas, assim como a inserção de notas de rodapé com direcionamento para os trechos pertinentes do Acórdão.
} 
Dentre os temas mais discutidos no julgamento, destaca-se a questão da anistia concedida a proprietários e produtores rurais que aderirem ao Programa de Regularização Ambiental (PRA). Para o Ministro Relator, Luiz Fux, os artigos 59 e 60 da Lei 12.651/2012, que dispõem sobre o Programa de Regularização Ambiental (PRA) e as hipóteses de suspensão da punibilidade por infrações administrativas e penais, seriam inconstitucionais por promoverem "verdadeira anistia condicional a esses infratores, em total desconformidade com o mandamento constitucional" (RELATOR..., 2017), referindo-se, no caso, ao artigo 225, parágrafo 30 , da Constituição de 1988 , que estabelece a responsabilização civil, penal e administrativa por condutas lesivas ao meio ambiente. Outra questão considerada inconstitucional no voto do relator foi a relativa à criação de regimes diferenciados de recomposição de vegetação para desmatamentos ilegais ocorridos antes e depois de 22/07/2008, sob o argumento de que não haveria "justificativa racional para o marco temporal estabelecido pelo legislador" (RELATOR..., 2017). ${ }^{32}$

Acompanhando o voto do relator, o Ministro Marco Aurélio reputou inconstitucional o marco temporal que estabeleceu regimes jurídicos diferentes de recomposição da vegetação, caso o desmatamento ilegal tenha ocorrido antes ou depois de 22/07/2008, pois não haveria fundamentação para a criação de um tratamento mais benevolente para aqueles que descumpriram a legislação. Apesar disso, a inconstitucionalidade do marco temporal não acarretaria, para este Ministro, a automática inconstitucionalidade do Programa de Regularização Ambiental (PRA), por entender que o referido

\footnotetext{
${ }^{32}$ Afirmou, ainda, que "o elemento normativo que incute inconstitucionalidade na medida de anistia aqui atacada é precipuamente a natureza do bem jurídico tutelado pelas normas cuja aplicação é obstaculizada. Com efeito, a extensão das anistias operadas pelo Código Florestal confronta o acolhimento do meio ambiente como direito fundamental, sobretudo por se tratar de bem jurídico indisponível e transindividual, cuja titularidade pertence a todos os cidadãos e ao próprio Estado. Não se trata de afirmar que o legislador não possa relativizar obrigações a qualquer título. Pelo contrário, trata-se de asseverar que, no presente caso, na medida em que impossibilitam a aplicação de qualquer tipo de sanção a infratores que cometeram condutas graves, verifica-se patente overenforcement do valor da atividade econômica, o que resvala em injustificado under-enforcement do valor da proteção ao meio ambiente. Essa situação fragiliza a normatividade da ordem constitucional ambiental". (BRASIL, 2019b, p. 94).
} 
programa não concede anistia ao produtor. ${ }^{33}$ Nas suas palavras, as "sanções são afastadas somente quando inteiramente cumprido o termo de compromisso" (BRASIL, 2019b, p. 23). ${ }^{34} 35$

O entendimento final do STF, por maioria, foi no sentido de atribuir ao tema interpretação conforme à Constituição (de modo que fosse afastado o risco de prescrição ou de decadência da punibilidade), reconhecendo, portanto, a validade da suspensão de sanções relativas a infrações anteriores a 22/07/2008 - marco temporal também tido, ao final, por constitucional. ${ }^{36} 0$ tribunal

${ }^{33}$ Sobre o Programa de Regularização Ambiental (PRA), segundo o Ministro Marco Aurélio: “A constatação da insuficiência das balizas concernentes ao regime de transição previsto nos artigos 61-A e seguintes não conduz à automática inconstitucionalidade do Programa de Regularização Ambiental, cujo objetivo é incentivar os produtores rurais a recomporem a vegetação, recebendo, em contrapartida, a conversão de multas em prestação de serviços de recuperação do meio ambiente e a extinção da punibilidade de produtores inscritos no mencionado programa, quando estritamente cumpridas as obrigações previstas em termo de compromisso. A criação de mecanismos voltados a incentivarem infratores a repararem os danos causados, com a correlata extinção da pena, são cada vez mais implementados como forma de superação da lógica meramente punitivista, a qual privilegia a reprimenda em detrimento da efetiva recomposição das consequências do ato ilegal. Essa perspectiva é verificada no próprio Direito Penal, no qual surge possível a transação penal, a suspensão condicional do processo ou, especificamente em relação a crimes tributários, a extinção da punibilidade quando reparado o dano antes do recebimento da denúncia. $\mathrm{A}$ solução proposta pelo legislador no Novo Código Florestal não diverge conceitualmente desse quadro. O programa consistiria em anistia caso viabilizasse a extinção da punibilidade independentemente da integral recomposição do dano ou afastasse sanções sem a efetiva e comprovada observância de balizas legais compatíveis com o mandamento constitucional de proteção ao meio ambiente. Não é essa a situação em jogo. O Programa de Regularização Ambiental possui balizas adequadas à promoção de política pública de tutela ambiental. De início, tem-se que os infratores devem celebrar termo de compromisso com o Poder Público, no qual discriminadas as obrigações a serem cumpridas, mediante rigoroso processo administrativo. A partir da assinatura do documento e enquanto estiverem sendo implementadas as medidas, os crimes terão a punibilidade suspensa". (BRASIL, 2019b, p. 178-179).

${ }^{34}$ Sobre o assunto, conferir a seguinte notícia: Código Florestal: ministro Marco Aurélio e ministra Carmén Lúcia apresentam seus votos. Disponível em: http://portal.stf.jus.br/noticias/verNoticiaDetalhe.asp?idConteudo=370270. Acesso em 28 Jan. 2019.

${ }^{35}$ Para o Ministro Marco Aurélio: "Inexiste justificativa racional para o tratamento diverso conferido às situações a partir da data de 22 de julho de 2008. O marco temporal revela-se arbitrário, surgindo inviável dele extrair fundamento plausível relacionado à tutela do meio ambiente ou à promoção da segurança jurídica. A formatação da política pública de proteção do meio ambiente, embora inserida em âmbito de atuação dos Poderes Executivo e Legislativo, pressupõe a seleção de critérios racional e cientificamente fundados. O legislador não pode escolher aleatoriamente a data que funciona como referencial nas obrigações de uso e recomposição ambiental. É impróprio estruturar regimes jurídicos diversos de proteção ambiental sem fundamentação razoável. O Direito deixa de ser sistema coerente para transformar-se em instrumento oscilante de ações políticas esparsas com curto horizonte temporal. Nada há a respaldar o tratamento mais benéfico conferido a proprietários de áreas ilegalmente devastadas até 22 de julho de 2008. O regime deve ser único e atender ao comando constitucional de proteção e recuperação de processos ecológicos essenciais. A constatação da inconstitucionalidade do referencial temporal relativo a 22 de julho de 2008, previsto nos artigos 7으, § 3으, e 17, § 3으, resulta, por decorrência lógica, na insubsistência do próprio regime de transição previsto nos artigos 59, § 4ㅇ, 61-A, 61-B, 61-C, 66 e 67. O mencionado marco consiste na espinha dorsal das situações abrangidas pelo tratamento diferenciado, mostrando-se impróprio mantê-lo sem a alusão à data balizadora". (BRASIL, 2019b, p. 177-178).

${ }^{36}$ O STF, "por maioria, deu interpretação conforme a Constituição ao art. 59, §4으, do Código Florestal, de modo a afastar, no decurso da execução dos termos de compromissos subscritos nos programas de regularização ambiental, 
considerou que a medida não configuraria uma anistia, tendo em vista que o descumprimento das obrigações previstas nos respectivos termos de compromisso acarreta a aplicação das sanções aos infratores. Na visão da Corte, o objetivo do artigo 59 do novo Código, em especial seus parágrafos 4ํe 5 ㅇ, seria o de facilitar a recuperação de áreas degradadas. ${ }^{37}$

O STF, além de confirmar que os proprietários e possuidores de imóveis rurais que tenham descumprido a legislação florestal antes de 22/07/2008 podem ser beneficiados, a partir da assinatura do Programa de Regularização Ambiental (PRA), com a suspensão das multas por infrações e da punibilidade dos crimes ambientais - relativas à supressão irregular de vegetação em Áreas de Preservação Permanente, de Reserva Legal e de uso restrito - cometidas antes daquela data, deixou de reconhecer a obrigação desses mesmos infratores de responderem civilmente pelo dano ambiental decorrentes da supressão indevida de vegetação protegida. Diz-se isso porque foi reconhecida, também por maioria, a constitucionalidade dos dispositivos que autorizam a continuidade de atividades agrossilvipastoris, de ecoturismo e de turismo rural em áreas consolidadas e, também, estabelecem parâmetros menos rigorosos - e, logo, menos protetivos do que os aplicáveis como regra geral - para manutenção de

o risco de decadência ou prescrição, seja dos ilícitos ambientais praticados antes de 22.7.2008, seja das sanções deles decorrentes, aplicando-se extensivamente o disposto no $\S 1$ 10 do art. 60 da Lei 12.651/2012, segundo o qual "a prescrição ficará interrompida durante o período de suspensão da pretensão punitiva", vencidos os Ministros Luiz Fux (Relator), Marco Aurélio, Edson Fachin, Roberto Barroso e Ricardo Lewandowski, e, em parte, o Ministro Gilmar Mendes". Seguindo a mesma lógica, "por maioria, deu interpretação conforme a Constituição ao art. 59, § 5o, do Código Florestal, de modo a afastar, no decurso da execução dos termos de compromissos subscritos nos programas de regularização ambiental, o risco de decadência ou prescrição, seja dos ilícitos ambientais praticados antes de 22.7.2008, seja das sanções deles decorrentes, aplicando-se extensivamente o disposto no § 1 o do art. 60 da Lei 12.651/2012, segundo o qual "a prescrição ficará interrompida durante o período de suspensão da pretensão punitiva", vencidos os Ministros Luiz Fux (Relator), Marco Aurélio, Edson Fachin, Roberto Barroso e Ricardo Lewandowski, e, em parte, o Ministro Gilmar Mendes". (BRASIL, 2019c, p. 642).

${ }^{37}$ Sobre o assunto, conferir a seguinte notícia: Julgamento do novo Código Florestal será retomado nesta quartafeira (21). Disponível em: http://www.stf.jus.br/portal/cms/verNoticiaDetalhe.asp?idConteudo=370065. Acesso em 22 fev. 2018 e BRASIL. Supremo Tribunal Federal. Notícias STF. Concluído julgamento de ações sobre novo Código Florestal. Disponível em: http://www.stf.jus.br/portal/cms/verNoticiaDetalhe.asp?idConteudo=370937. Acesso em 12 abr. 2018. 
vegetação em APPs ao longo ou no entorno de cursos d'água, lagos e lagoas naturais em áreas consolidadas, $^{38}$ assim como para a manutenção e recomposição das RLs em áreas consolidadas. ${ }^{39}$

Em resumo, o STF considerou constitucional o estabelecimento de dois regimes jurídicos diferentes, quais sejam: (i) o regime mais rigoroso, com parâmetros mais protetivos e com maiores restrições à supressão de vegetação, aplica-se como regra geral àquelas propriedades em que a legislação florestal foi regularmente cumprida até 22/07/2008; (ii) o regime mais permissivo, com parâmetros bem menos protetivos e com menores restrições à ocupação de APPs, aplica-se, ironicamente e de modo não isonômico, àquelas propriedades que apresentem ocupação antrópica (com edificações, benfeitorias ou atividades agrossilvipastoris) irregular, por vezes criminosa e caracterizada como dano ambiental, desde que a irregularidade seja preexistente a 22/07/2008.

Foi declarada a constitucionalidade dos artigos 61-A, 61-B, 61-C, 63 e 67, sob o fundamento de que ao Poder Legislativo caberia legitimidade constitucional para criação de regimes de transição entre marcos regulatórios, considerando que os artigos mencionados abordam apenas critérios para recomposição da vegetação, sem levar em consideração o flagrante desrespeito ao princípio da isonomia ao diferenciar parâmetros de proteção ambiental. Da mesma forma, ao considerar válido o critério do tamanho da propriedade para cálculo da metragem da área a ser recomposta, ignorou-se por completo o princípio da vedação ao retrocesso, posto que se legitimou o desmatamento ilegal ocorrido anteriormente ao marco temporal de 22/07/2008, assim como foram reduzidos substancialmente padrões mínimos de proteção ambiental, que já se encontravam estabelecidos e em vigor pela legislação revogada pelo atual Código Florestal (BRASIL, 2019b, p. 19).

\footnotetext{
${ }^{38}$ Sobre os dispositivos em comento, decidiu o STF, "por maioria, vencidos os Ministros Marco Aurélio e Ricardo Lewandowski, e, em parte, o Ministro Edson Fachin, reconhecer a constitucional do art. 61-A do Código Florestal"; também por maioria, "vencidos os Ministros Marco Aurélio, Edson Fachin e Ricardo Lewandowski, reconhecer a constitucionalidade do art. 61-B do Código Florestal"; e, "por maioria, vencidos os Ministros Marco Aurélio, Edson Fachin e Ricardo Lewandowski, reconhecer a constitucionalidade do art. 61- C do Código Florestal". (BRASIL, 2019b, p. 671-672).

39 O STF decidiu, "por maioria, vencidos os Ministros Marco Aurélio, Edson Fachin, Rosa Weber e Ricardo Lewandowski, reconhecer a constitucionalidade do art. 66, § 3ㅇ, do Código Florestal"; "por maioria, vencidos os Ministros Marco Aurélio, Edson Fachin, e, em parte, o Ministro Ricardo Lewandowski, reconhecer a constitucionalidade do art. 66, § 50, do Código Florestal"; "por maioria, vencidos os Ministros Marco Aurélio, Edson Fachin, e, em parte, o Ministro Ricardo Lewandowski, reconhecer a constitucionalidade do art. 66, § 60, do Código Florestal"; "por maioria, vencidos os Ministros Marco Aurélio, Cármen Lúcia (Presidente), Edson Fachin, Rosa Weber e Ricardo Lewandowski, reconhecer a constitucionalidade do art. 67 do Código Florestal"; e "por maioria, vencido, em parte, o Ministro Edson Fachin, reconhecer a constitucionalidade do art. 68 do Código Florestal". (BRASIL, 2019b, p. 665).
} 
Como o artigo 225, parágrafo 3으, da Constituição Federal institui a tríplice responsabilização ambiental (penal, administrativa e civil) para aqueles que praticarem condutas lesivas ao meio ambiente, sobressai do julgamento uma incômoda sensação de "legalização" do dano ambiental em razão de não se ter considerada a incompatibilidade dos artigos 59 e seguintes da Lei 12.651/2012 com a normativa constitucional. Em outras palavras: a suspensão de penalidades administrativas ou criminais, seguida da sua extinção em razão do cumprimento de obrigações estabelecidas no PRA ou no termo de compromisso, não deveria afastar o dever constitucional, autônomo, de recuperação do dano ambiental causado. Ocorre que a Lei 12.651/2012, ao estabelecer parâmetros mais flexíveis para a regularização do uso de áreas rurais consolidadas, acaba por "legalizar", sem qualquer compensação, a existência e perpetuação do dano ambiental, e, também, autorizar uso que compromete a integridade dos atributos que justificam a proteção esperada para o espaço protegido (seja APP ou RL), em dissonância com o disposto no parágrafo 1ำ, inciso III, e 3ำ, do artigo 225 da Constituição Federal. Soma-se a isso, mais uma vez, a violação ao princípio da isonomia, já que padrões protetivos mais rigorosos continuam sendo exigidos em propriedades que, regularmente, sempre observaram e respeitaram a legislação florestal.

Dentre os dispositivos que receberam interpretação conforme, de modo a afastar sua inconstitucionalidade, merecem destaque os artigos 3으, incisos XVII e XVIII, e 4으, inciso IV, da Lei $12.651 / 2012,{ }^{40}$ que ora excluem ora garantem a proteção das nascentes e olhos d'água intermitentes. Neste caso, o STF fixou o entendimento de que são áreas de preservação permanente o entorno de nascentes e olhos d'água perenes ou intermitentes. ${ }^{41}$

\footnotetext{
${ }^{40}$ Nos termos do artigo 3o, "entende-se por: [...] VII - nascente: afloramento natural do lençol freático que apresenta perenidade e dá início a um curso d'água; XVIII - olho d'água: afloramento natural do lençol freático, mesmo que intermitente" (BRASIL, 2012a).

Já o artigo 40 considera "Área de Preservação Permanente, em zonas rurais ou urbanas, para os efeitos desta Lei: [...] IV - as áreas no entorno das nascentes e dos olhos d'água perenes, qualquer que seja sua situação topográfica, no raio mínimo de 50 (cinquenta) metros" (BRASIL, 2012a).

${ }^{41} \mathrm{Em}$ sua decisão final, decidiu o STF, "por maioria, vencidos os Ministros Gilmar Mendes, e, em parte, a Ministra Cármen Lúcia (Presidente), dar interpretação conforme a Constituição ao art. 3o, XVII, do Código Florestal, para fixar a interpretação de que os entornos das nascentes e dos olhos d'água intermitentes configuram área de preservação permanente"; assim como, também "por maioria, dar interpretação conforme ao art. 4으, IV, do Código Florestal, para fixar a interpretação de que os entornos das nascentes e dos olhos d'água intermitentes configuram área de preservação ambiental, vencidos o Ministro Gilmar Mendes e, em parte, os Ministros Marco Aurélio e Cármen Lúcia (Presidente)". (BRASIL, 2019d, p. 665).
} 
Quanto à intervenção excepcional em APPs por interesse social ou utilidade pública, prevista no artigo 8o da Lei $12.651 / 2012,{ }^{42}$ o STF determinou que esta fica condicionada também à inexistência de alternativa técnica ou locacional à atividade proposta. ${ }^{43}$ Além disso, foram reduzidos os casos considerados de utilidade pública previstos no artigo 3ำ, inciso VIII, alínea "b" do novo Código, tendo sido excluídas da lista, por inconstitucionais, as obras de gestão de resíduos e as vinculadas à realização de competições esportivas. ${ }^{44}$

Sem a pretensão de esgotar a análise do julgamento final sobre cada dispositivo reputado inconstitucional nas ações propostas, deve-se destacar que a declaração de inconstitucionalidade se limitou a questões pontuais do Código Florestal, enquanto assuntos sensíveis, como a anistia de infratores ambientais da obrigação de recuperar integralmente os passivos de Reserva Legal e Área de Preservação Permanente, foram validados pelo STF. Como já destacado, a legitimação e a perpetuação dos danos ambientais foram confirmadas a partir do momento em que se considerou constitucional a existência de dois regimes jurídicos diferentes de proteção das APPs e RLs, sendo o mais rigoroso exigido como regra geral e o mais brando e menos protetivo exigido em áreas consolidadas, submetidas à supressão irregular de sua vegetação até o dia 22/07/2008.

Deve-se destacar, ainda, que, nos termos do voto do Ministro Relator Luiz Fux, a aplicação do princípio da vedação ao retrocesso, no caso em tela, foi rechaçada sem debate aprofundado a respeito da teoria que embasa o princípio e em descompasso com a própria interpretação do Supremo Tribunal

\footnotetext{
${ }^{42} \mathrm{O}$ artigo 80 dispõe que "A intervenção ou a supressão de vegetação nativa em Área de Preservação Permanente somente ocorrerá nas hipóteses de utilidade pública, de interesse social ou de baixo impacto ambiental previstas nesta Lei".

${ }^{43}$ Decidiu-se, "por maioria, dar interpretação conforme a Constituição ao art. 3ํ, VIII e IX, do Código Florestal, de modo a se condicionar a intervenção excepcional em APP, por interesse social ou utilidade pública, à inexistência de alternativa técnica e/ou locacional à atividade proposta, vencidos, em parte, os Ministros Gilmar Mendes e Celso de Mello". (BRASIL, 2019d, p. 665).

44 O STF decidiu, "por maioria, vencidos os Ministros Edson Fachin e Gilmar Mendes, e, em parte, o Ministro Alexandre de Moraes, declarar a inconstitucionalidade das expressões "gestão de resíduos" e "instalações necessárias à realização de competições esportivas estaduais, nacionais ou internacionais", contidas no art. 3으, VIII, b, da Lei 12.651/2012 (Código Florestal) ". (BRASIL, 2019d, p. 664).
} 
Federal em julgados anteriores. ${ }^{45} \mathrm{~A}$ despeito da menção à melhor doutrina, ${ }^{46} \mathrm{O}$ Ministro Relator considerou-a minoritária e desvirtuou o princípio em questão com base em argumentos que acabam por desconsiderar sua importância e, mesmo, sua própria essência, tais como: impedimento do dinamismo da atividade legiferante do Estado, engessamento de políticas públicas, falta de previsão constitucional, interesses de mercado e trabalho e falta de competência do judiciário para analisar políticas públicas implementadas pelo Legislativo. ${ }^{47} \mathrm{O}$ Ministro Relator deixou de aplicar e relativizou toda uma construção principiológica do próprio Tribunal ao escolher considerar as alterações do Código Florestal como avanços na concretização de objetivos constitucionais, quando, em realidade, são afrontas diretas ao Direito posto e à proteção de espaços territoriais especialmente protegidos. O suposto engessamento que o princípio poderia causar, de acordo com o voto do Relator, é na verdade a tentativa de impedir alterações legislativas que fragilizam o arcabouço jurídico construído e, em especial, o seu núcleo essencial. Não se trata, portanto, de um engessamento, mas, ao contrário, de uma das últimas formas de impedir que sejam relativizados direitos fundamentais. O voto em questão, ao invés de fortalecer o entendimento da própria

\footnotetext{
${ }^{45}$ Como mencionado ao final do item 1 deste ensaio, o STF já reconheceu o mínimo existencial socioambiental que deve ser protegido contra a ação legislativa e administrativa em matéria ambiental, capaz de vulnerar o núcleo essencial do direito fundamental ao meio ambiente ecologicamente equilibrado, previsto no art. 225 da Constituição da República. Julgados do STF, anteriores e posteriores aos acórdãos relativos ao Código Florestal de 2012, pautamse na aplicação do princípio da vedação ao retrocesso socioambiental para impedir que sejam desconstituídos direitos fundamentais conquistados pelos cidadãos, configurando, sim, obstáculo às reformas legislativas cujas alterações visem à diminuição e ao enfraquecimento de direitos por medidas estatais ulteriores, cujas intenções esvaziam o núcleo essencial que se pretendeu proteger quando da efetivação desses direitos. (BRASIL, 2011; 2018; 2020).

${ }^{46}$ Autores como José Gomes Canotilho (2003), Michel Prieur (2012) e Ingo Sarlet e Tiago Fensterseifer (2010 e 2017), dentre outros.

${ }^{47}$ Trechos do voto do Ministro Relator Luiz Fux a respeito do princípio da vedação ao retrocesso que vão de encontro ao que neste artigo se buscou demonstrar: "Evidencia-se, à luz do exposto, que a revisão judicial das premissas empíricas que embasam determinada medida regulatória, quanto mais quando editada pelo legislador democrático, não pode ocorrer pela singela e arbitrária invocação de um suposto "retrocesso" na defesa do meio ambiente. Na realidade, os proponentes da denominada "teoria da vedação do retrocesso" entendem existente um estado de Inconstitucionalidade quando eliminada determinada norma infraconstitucional ou estrutura material essencial para a concretização mínima de um comando explícito da Carta Magna." [...] "Entender como "vedação ao retrocesso" qualquer tipo de reforma legislativa ou administrativa que possa causar decréscimo na satisfação de um dado valor constitucional seria ignorar um elemento básico da realidade: a escassez. Rememore-se que, frequentemente, legisladores e administradores somente poderão implementar avanços na concretização de determinados objetivos constitucionais por meio de medidas que causam efeitos negativos em outros objetivos igualmente caros ao constituinte. $O$ engessamento das possibilidades de escolhas na formulação de políticas públicas, a impedir a redistribuição de recursos disponíveis entre as diversas finalidades carentes de satisfação na sociedade, em nome de uma suposta "vedação ao retrocesso" sem base no texto constitucional, viola o núcleo básico do princípio democrático e transfere indevidamente ao Judiciário funções inerentes aos Poderes Legislativo e Executivo" (BRASIL, 2019b, p. 61-66).
} 
Corte e a proteção dos direitos fundamentais da sociedade brasileira em geral, enfraquece e distorce princípio constitucional crucial para a defesa do meio ambiente e dos direitos humanos.

À luz do exposto, entende-se que o STF, ao declarar a constitucionalidade da maioria dos dispositivos do novo Código Florestal (Lei 12.651/2012), não cumpriu adequadamente com seu papel de guardião da Constituição; antes, chancelou a consolidação de significativos retrocessos normativos relativos à proteção das florestas e demais formas de vegetação, enfraquecendo e desvirtuando importantes institutos jurídicos como as APPs e as RLs que, ao deixarem de desempenhar suas funções ambientais (a exemplo da preservação dos recursos hídricos, da paisagem, da estabilidade geológica e da biodiversidade) ${ }_{1}^{48}$ perdem sua principal razão de existir, ferindo-se gravemente o núcleo essencial do direito fundamental ao meio ambiente ecologicamente equilibrado.

Os retrocessos trazidos pelo Código Florestal de 2012, e chancelados pelo Supremo Tribunal Federal, vão de encontro a toda a fundamentação teórica do princípio da vedação ao retrocesso socioambiental e, em última análise, à própria proteção do núcleo essencial do direito fundamental ao meio ambiente ecologicamente equilibrado. A proteção desse direito foi preterida pelo Legislativo, que reformou a norma florestal, diminuindo - de forma não isonômica e inconstitucional, como se buscou demonstrar - os parâmetros legais de proteção desses espaços territoriais especialmente protegidos. Ao desconsiderar seu próprio entendimento sobre o princípio da vedação ao retrocesso socioambiental, o STF perdeu a oportunidade de confirmar o seu papel de guardião da Constituição e atendeu a finalidades político-econômicas que lhe pareceram mais interessantes à época, em detrimento da integridade e equilíbrio do meio ambiente enquanto macrobem.

\footnotetext{
48 Para a identificação das funções ambientais desempenhadas pelas APPs e RLs, vale conferir as respectivas definições legais, dispostas no artigo 20 da Lei 12.651/2012 (BRASIL, 2012a):

"II - Área de Preservação Permanente - APP: área protegida, coberta ou não por vegetação nativa, com a função ambiental de preservar os recursos hídricos, a paisagem, a estabilidade geológica e a biodiversidade, facilitar o fluxo gênico de fauna e flora, proteger o solo e assegurar o bem-estar das populações humanas;

III - Reserva Legal: área localizada no interior de uma propriedade ou posse rural, delimitada nos termos do art. 12, com a função de assegurar o uso econômico de modo sustentável dos recursos naturais do imóvel rural, auxiliar a conservação e a reabilitação dos processos ecológicos e promover a conservação da biodiversidade, bem como o abrigo e a proteção de fauna silvestre e da flora nativa".
} 


\section{CONCLUSÃO}

Este ensaio teve com ponto de partida o estado atual do arcabouço jurídico-ambiental brasileiro, tendo sido sinalizado que o grande desafio contemporâneo quanto à tutela do meio ambiente deixou de residir somente na necessidade de efetiva implementação de diplomas normativos já existentes e, logo, na correção da discrepância entre o direito legislado e o direito aplicado, caracterizadora de um "Estado Teatral" (BENJAMIN, 2010).

O centro das atenções em matéria de Direito Ambiental deve se deslocar para o enfrentamento das tendências retrocessivas de enfraquecimento da tutela jurídico-ambiental no Brasil, tendo em vista a edição - consolidada ou iminente - de diplomas normativos que violam o núcleo essencial do direito fundamental ao meio ambiente equilibrado e, como consequência, impedem a proteção progressiva (ou mesmo a manutenção) deste direito humano.

O principal exemplo de retrocesso socioambiental já implementado é a Lei 12.651/2012, conhecida como novo Código Florestal. Sob o pretexto de aperfeiçoar a legislação florestal brasileira, editou-se uma lei que enfraquece de modo substancial importantes instrumentos jurídicos de proteção ambiental: as Áreas de Preservação Permanente e as Reservas Legais. Pelas razões expostas ao longo do texto, dentre as quais se destaca a anistia aos degradadores ambientais que desmataram suas propriedades ilegalmente antes de 22/07/2008, dispensando-os da obrigação de promover a integral reparação dos danos ambientais, pode-se afirmar que a Lei 12.651/2012 foi editada em desacordo com o sistema jurídico-ambiental construído a partir da Lei 6.938/1981 e coroado com a constitucionalização, em 1988, da tutela do meio ambiente, ao qual se atribuiu status de direito humano fundamental.

Embora tenham sido propostas diversas ações diretas de inconstitucionalidade junto ao STF, a grande maioria dos dispositivos do novo Código Florestal foi declarada constitucional pela referida Corte, em especial a referida anistia concedida aos proprietários e produtores rurais que desmataram ilegalmente suas terras até 22/07/2008, tendo sido validados retrocessos normativos em matéria de meio ambiente, em inobservância ao princípio da proibição do retrocesso socioambiental; pior, promoveu-se verdadeiro esvaziamento do conteúdo do referido princípio.

Tendo em vista o panorama de (des)proteção ambiental que o novo Código Florestal apresenta, aliado às fortes tendências retrocessivas enfrentadas em outras áreas do Direito Ambiental, a mobilização 
e a densificação do princípio da vedação ao retrocesso socioambiental torna-se indispensável. Infelizmente, não parece ter sido este o entendimento do STF. Ao contrário, a Corte constitucional brasileira acabou por confirmar e legitimar retrocessos jurídico-ambientais, ao considerar como constitucionais um conjunto de dispositivos que afrontam diretamente o núcleo essencial do direito ao meio ambiente ecologicamente equilibrado. Trata-se de decisão histórica, por lamentáveis razões.

\section{REFERÊNCIAS BIBLIOGRÁFICAS}

BENJAMIN, Antônio Herman de Vasconcellos e. Objetivos do direito ambiental. In: BENJAMIN, Antônio Herman de Vasconcellos e; sícOLI, J. C. M. (Coord.). O futuro do controle da poluição e da implementação ambiental. São Paulo: Instituto O Direito por um Planeta Verde; Procuradoria Geral de Justiça de São Paulo, 2001. p. 56-78. Disponível em:

<http://bdjur.stj.jus.br/dspace/handle/2011/30106>. Acesso em: 01 out. 2017.

BENJAMIN, Antônio Herman de Vasconcellos. O estado teatral e a implementação do direito ambiental. Brasília: BDJur. 2010. In: Direito, água e vida: law, water and the web of life. v. 1, [s.d.], 2010, p. 335-366. Disponível em: https://bdjur.stj.jus.br/jspui/handle/2011/30604. Acesso em 17 Nov. 2017.

BRASIL. Constituição de 1934. Constituição dos Estados Unidos do Brasil. Rio de Janeiro, 1934. Disponível em: http://www.planalto.gov.br/ccivil_03/constituicao/constituicao34.htm. Acesso em 26 abr. 2019. (BRASIL, 1934).

BRASIL. Constituição da República Federativa do Brasil de 1988. Brasília, 05 de outubro de 1988. Disponível em: http://www.planalto.gov.br/ccivil_03/constituicao/constituicao.htm. Acesso em 26 abr. 2019. (Brasil, 1988).

BRASIL. Decreto 591, de 6 de julho de 1992. Pacto Internacional sobre Direitos Econômicos, Sociais e Culturais. Promulgação. Disponível em: http://www.planalto.gov.br/ccivil_03/decreto/19901994/d0591.htm. Acesso em 13 out. 2020. (BRASIL, 1992). BRASIL. Decreto 3.321, de 30 de dezembro de 1999. Promulga o Protocolo Adicional à Convenção Americana sobre Direitos Humanos em Matéria de Direitos Econômicos, Sociais e Culturais "Protocolo de São Salvador", concluído em 17 de novembro de 1988, em São Salvador, El Salvador. Disponível em: http://www.planalto.gov.br/ccivil_03/decreto/d3321.htm. Acesso em 13 out. 2020. (BRASIL, 1999).

BRASIL. Decreto 6.514, de 22 de julho de 2008. Dispõe sobre as infrações e sanções administrativas ao meio ambiente, estabelece o processo administrativo federal para apuração destas infrações, e dá outras providências. Disponível em: http://www.planalto.gov.br/ccivil_03/_ato20072010/2008/decreto/d6514.htm. Acesso em 13 out. 2020. (BRASIL, 2008).

BRASIL. Decreto 7.830, de 17 de outubro de 2012. Dispõe sobre o Sistema de Cadastro Ambiental Rural, o Cadastro Ambiental Rural, estabelece normas de caráter geral aos Programas de Regularização Ambiental, de que trata a Lei no 12.651, de 25 de maio de 2012, e dá outras providências. Disponível em: 
http://www.planalto.gov.br/ccivil_03/_ato2011-2014/2012/decreto/d7830.htm. Acesso em 13 out. 2020. (Brasil, 2012b).

BRASIL. Lei 4.771, de 15 de setembro de 1965. Institui o novo Código Florestal. (Revogada pela Lei 12.651, de 25 de maio de 2012. Novo Código Florestal) Disponível em:

http://www.planalto.gov.br/ccivil_03/leis/I4771.htm. Acesso em 13 out. 2020. (BRASIL, 1965)

BRASIL. Lei 6.938, de 2 de setembro de 1981. Institui a Política Nacional do Meio Ambiente. Brasília. Disponível em: http://www.planalto.gov.br/ccivil_03/leis/L6938compilada.htm. Acesso em 02 out. 2020. (Brasil, 1981).

BRASIL. Lei 9.605, de 12 de fevereiro de 1998. Dispõe sobre as sanções penais e administrativas derivadas de condutas e atividades lesivas ao meio ambiente, e dá outras providências. Disponível em: http://www.planalto.gov.br/ccivil_03/leis/l9605.htm. Acesso em 13 out. 2020. (BRASIL, 1998).

BRASIL. Lei 11.105, de 24 de março de 2005. Regulamenta os incisos II, IV e V do § 1 ㅇ do art. 225 da Constituição Federal, estabelece normas de segurança e mecanismos de fiscalização de atividades que envolvam organismos geneticamente modificados - OGM e seus derivados, cria o Conselho Nacional de Biossegurança - CNBS, reestrutura a Comissão Técnica Nacional de Biossegurança - CTNBio, dispõe sobre a Política Nacional de Biossegurança - PNB, revoga a Lei 8.974, de 5 de janeiro de 1995, e a Medida Provisória 2.191-9, de 23 de agosto de 2001, e os arts. 5ㅇ, 6으, 7으, 8o, 9ㅇ, 10 e 16 da Lei 10.814, de 15 de dezembro de 2003, e dá outras providências. Disponível em: http://www.planalto.gov.br/ccivil_03/_ato2004-2006/2005/lei/l11105.htm. Acesso em 13 out. 2020. (BRASIL, 2005).

BRASIL. Lei 12.651, de 25 de maio de 2012. Novo Código Florestal. Brasília. Disponível em: http://www.planalto.gov.br/ccivil_03/_ato2011-2014/2012/lei/L12651compilado.htm. Acesso em 09 out. 2020. (BRASIL, 2012a).

BRASIL. Supremo Tribunal Federal (Tribunal Pleno). Mandado de Segurança 22.164-SP. Rel. Relator: Ministro Celso de Mello. Brasília, 30 de outubro de 1995. Disponível em http://redir.stf.jus.br/paginadorpub/paginador.jsp?docTP=AC\&doclD=85691. Acesso em 02 mar. 2019. (BRASIL, 1995).

BRASIL. Lei 13.887, de 17 de outubro de 2019. Altera a Lei 12.651, de 25 de maio de 2012, que dispõe sobre a proteção da vegetação nativa e dá outras providências. Disponível em: planalto.gov.br/ccivil_03/_ato2019-2022/2019/lei/L13887.htm. Acesso em 13 out. 2020. (BRASIL, 2019f).

BRASIL. Supremo Tribunal Federal (Tribunal Pleno). Ação Declaratória de Constitucionalidade 42-DF. Relator: Ministro Luiz Fux. Brasília, 13 de agosto de 2019. Disponível em http://redir.stf.jus.br/paginadorpub/paginador.jsp?docTP=TP\&docID=750504017. Acesso em 21 ago. 2019. (BRASIL, 2019a).

BRASIL. Supremo Tribunal Federal (Tribunal Pleno). Ação Direta de Inconstitucionalidade 4.717-DF. Relatora: Ministra Carmen Lúcia. Brasília, 05 de abril de 2018. Disponível em 
http://redir.stf.jus.br/paginadorpub/paginador.jsp?docTP=TP\&docID=749158743. Acesso em 21 ago. 2019. (BRASIL, 2018).

BRASIL. Supremo Tribunal Federal (Tribunal Pleno). Ação Direta de Inconstitucionalidade 4.901-DF. Relator: Ministro Luiz Fux. Brasília, 13 de agosto de 2019. Disponível em http://redir.stf.jus.br/paginadorpub/paginador.jsp?docTP=TP\&docID=750504532. Acesso em 21 ago. 2019. (BRASIL, 2019b).

BRASIL. Supremo Tribunal Federal (Tribunal Pleno). Ação Direta de Inconstitucionalidade 4.902-DF. Relator: Ministro Luiz Fux. Brasília, 13 de agosto de 2019. Disponível em http://redir.stf.jus.br/paginadorpub/paginador.jsp?docTP=TP\&doclD=750504579. Acesso em 21 ago. 2019. (BRASIL, 2019c).

BRASIL. Supremo Tribunal Federal (Tribunal Pleno). Ação Direta de Inconstitucionalidade 4.903-DF. Relator: Ministro Luiz Fux. Brasília, 13 de agosto de 2019. Disponível em http://redir.stf.jus.br/paginadorpub/paginador.jsp?docTP=TP\&doclD=750504464. Acesso em 21 ago. 2019. (BRASIL, 2019d).

BRASIL. Supremo Tribunal Federal (Tribunal Pleno). Ação Direta de Inconstitucionalidade 4.937-DF. Relator: Ministro Luiz Fux. Brasília, 13 de agosto de 2019. Disponível em http://redir.stf.jus.br/paginadorpub/paginador.jsp?docTP=TP\&docID=750504017. Acesso em 21 ago. 2019. (BRASIL, 2019e).

BRASIL. Supremo Tribunal Federal (2. Turma). Agravo Regimental no Recurso Extraordinário 639.337SP. Relator: Ministro Celso de Mello. Brasília, 23 de outubro de 2011. Disponível em http://redir.stf.jus.br/paginadorpub/paginador.jsp?docTP=TP\&doclD=750504017. Acesso em 21 ago. 2019. (BRASIL, 2011).

BRASIL. Supremo Tribunal Federal (Tribunal Pleno). Medida Cautelar na Arguição de Descumprimento de Preceito Fundamental 656-DF. Relator: Ministro Ricardo Lewandowski. Brasília, 22 de junho de 2020. Disponível em http://redir.stf.jus.br/paginadorpub/paginador.jsp?docTP=TP\&doclD=753655549. Acesso em 08 out. 2020. (BRASIL, 2020).

CANOTILHO, José Joaquim Gomes. Direito Constitucional e Teoria da Constituição. 7ạ ed. Coimbra: Almedina, 2003. 1.522p.

CORTE INTERAMERICANA DE DIREITOS HUMANOS. Opinião Consultiva OC 23-2017. Meio ambiente e direitos humanos. 15 de novembro de 2017. Disponível em http://www.corteidh.or.cr/docs/opiniones/seriea_23_esp.pdf. Acesso em 10 abr. 2019.

FENSTERSEIFER, Tiago. Direitos fundamentais e proteção do ambiente: a dimensão ecológica da dignidade humana no marco jurídico constitucional do estado socioambiental de direito. Porto Alegre: Livraria do Advogado Editora, 2008.

INSTITUTO SOCIOAMBIENTAL. Petição de ingresso como amicus curiae nas ações que questionam a constitucionalidade da Lei 12.651/2012. 2015. Disponível em: 
https://www.socioambiental.org/sites/blog.socioambiental.org/files/nsa/arquivos/amicus_curiae__05.08.2015.pdf. Acesso em 22 abr. 2019.

CHIAVARI, Joana; LOPES, Cristina Leme. Nota Técnica. Jabutis de diferentes espécies e tamanhos ameaçam o novo Código Florestal. Rio de Janeiro: Climate Policy Initiative, 2019. Disponível em: https://climatepolicyinitiative.org/wp-content/uploads/2019/03/INPUT-Nota_TecnicaMedida_Provisoria-26Mar-PT.pdf. Acesso em 25 abr. 2019.

LIMA, André; BENSUSAN, Nurit; RUSS, Lian. Código Florestal: por um debate pautado em ciência. Brasília: Instituto de Pesquisa Ambiental da Amazônia (IPAM), 2014. p. 9. Disponível em http://www.ipam.org.br/biblioteca/livro/Estudo-do-Ipam-mergulha-na-producao-cientifica-existentepara-entender-importancia-das-florestas/761 Acesso em 27 out. 2015.

MACHADO, Paulo Affonso Leme. Direito Ambiental Brasileiro. 22a ed. São Paulo: Malheiros Editores LTDA, 2014. 1344p.

MORAES, Maria Celina Bodin de. O Princípio da Solidariedade. In: PEIXINHO, Manoel Messias; Guerra, Isabella Franco; NASCIMENTO FILHO, Firly (Org.). Os Princípio das Constituição de 1988. Rio de Janeiro: Lumen Juris, 2006.

PRIEUR, Michel. O princípio da proibição de retrocesso ambiental. In: Senado Federal. Princípio da Proibição de Retrocesso Ambiental. Brasília: Senado Federal, 2012. p. 11 - 54. Disponível em <http://www2.senado.gov.br/bdsf/handle/id/242559 > Acesso em 20 de out. 2015.

ONU. Declaração Universal dos Direitos Humanos. 1948. Disponível em: https://www.unicef.org/brazil/declaracao-universal-dos-direitos-humanos. Acesso em 13 out. 2020. (ONU, 1948).

ONU. Declaração de Estocolmo sobre meio ambiente humano. 1972. Disponível em: http://portal.iphan.gov.br/uploads/ckfinder/arquivos/Declaracao\%20de\%20Estocolmo\%201972.pdf. Acesso em 13 out. 2020. (ONU, 1972)

RELATOR profere voto no julgamento sobre novo Código Florestal. Notícia do Supremo Tribunal Federal. 08 de novembro de 2017. Disponível em:

http://www.stf.jus.br/portal/cms/verNoticiaDetalhe.asp?idConteudo=361342. Acesso em 11 nov. 2019.

RODRIGUES, Marcelo Abelha. Áreas consolidadas no Código Florestal (Lei 12.651/2012): Uma vergonha sem precedentes no Direito Ambiental brasileiro. Revista de Direito Ambiental. v. 18, n. 69, jan./mar. 2013, p. 345-356.

SARLET, Ingo Wolfgang e FENSTERSEIFER, Thiago. Breves considerações sobre a proibição de retrocesso em matéria ambiental à luz do atual cenário de flexibilização da legislação ecológica brasileira. In: $22^{\circ}$ Congresso Brasileiro de Direito Ambiental, 2017, São Paulo. Jurisprudência, ética e justiça ambiental no século XXI. São Paulo: Instituto o Direito por um Planeta Verde, 2017. v. 1. p. 199-240. 
SARLET, Ingo Wolfgang; FENSTERSEIFER, Tiago. Breves Considerações sobre os deveres de proteção do Estado e a garantia da proibição do retrocesso em matéria ambiental. Revista de Direito Ambiental. São Paulo, n. 58, p. $41-85$, abr./jun. 2010.

SOCIEDADE BRASILEIRA PARA O PROGRESSO DA CIÊNCIA. ACADEMIA BRASILEIRA DE CIÊNCIAS. O Código Florestal e a Ciência: Contribuições para o Diálogo. São Paulo: SBPC, SBPC; Academia Brasileira de Ciências, ABC, 2011. 124p. Disponível em http://www.abc.org.br/IMG/pdf/doc-547.pdf. Acesso em 08 abr. 2019. (SBPC, 2011)

Trabalho enviado em 07 de agosto de 2019 Aceito em 16 de janeiro de 2021 